OPEN ACCESS

Edited by:

Or Kakhlon,

Hadassah Medical Center, Israel

Reviewed by:

Ross F. Collery,

Medical College of Wisconsin,

United States

Maysa Mariana Cruz,

Federal University of São Paulo, Brazil

*Correspondence:

Javier S. Perona

perona@ig.csic.es

Specialty section:

This article was submitted to

Molecular Medicine,

a section of the journal

Frontiers in Cell and Developmental

Biology

Received: 24 April 2020

Accepted: 01 September 2020

Published: 14 October 2020

Citation:

Castellano JM, Espinosa JM and Perona JS (2020) Modulation of Lipid

Transport and Adipose Tissue Deposition by Small Lipophilic

Compounds.

Front. Cell Dev. Biol. 8:555359. doi: 10.3389/fcell.2020.555359

\section{Modulation of Lipid Transport and Adipose Tissue Deposition by Small Lipophilic Compounds}

\author{
José M. Castellano, Juan M. Espinosa and Javier S. Perona* \\ Group of Bioactive Compounds, Nutrition and Health, Department of Food and Health, Instituto de la Grasa-Consejo \\ Superior de Investigaciones Cientificas, Seville, Spain
}

Small lipophilic molecules present in foods of plant origin have relevant biological activities at rather low concentrations. Evidence suggests that phytosterols, carotenoids, terpenoids, and tocopherols can interact with different metabolic pathways, exerting beneficial effects against a number of metabolic diseases. These small molecules can modulate triacylglycerol absorption in the intestine and the biosynthesis of chylomicrons, the lipid carriers in the blood. Once in the bloodstream, they can impact lipoprotein clearance from blood, thereby affecting fatty acid release, incorporation into adipocytes and triglyceride reassembling and deposit. Consequently, some of these molecules can regulate pathophysiological processes associated to obesity and its related conditions, such as insulin resistance, metabolic syndrome and type-2 diabetes. The protective capacity of some lipophilic small molecules on oxidative and chemotoxic stress, can modify the expression of key genes in the adaptive cellular response, such as transcription factors, contributing to prevent the inflammatory status of adipose tissue. These small lipophilic compounds can be incorporated into diet as natural parts of food but they can also be employed to supplement other dietary and pharmacologic products as nutraceuticals, exerting protective effects against the development of metabolic diseases in which inflammation is involved. The aim of this review is to summarize the current knowledge of the influence of dietary lipophilic small biomolecules (phytosterols, carotenoids, tocopherols, and triterpenes) on lipid transport, as well as on the effects they may have on pathophysiological metabolic states, related to obesity, insulin resistance and inflammation, providing an evidence-based summary of their main beneficial effects on human health.

Keywords: tocopherol, carotenoid, sterol, triterpene, metabolism, metabolic disease

\section{INTRODUCTION}

Among lipophilic compounds exerting biological effects on human health, phytosterols, carotenoids, tocopherols, and triterpenes are consumed as part of food. To exert their benefit, they need to be released from the food matrix and be available for intestinal absorption (Saura-Calixto et al., 2007); this involves micelle formation and emulsification by bile, interaction with enzymes in the intestinal lumen, and further hydrolysis by pancreatic lipases, if they were esterified with fatty acids (Iqbal and Hussain, 2009). 
Latest studies using the human epithelial colorectal adenocarcinoma (CaCo-2) cell line have proved that the uptake of these substances is mediated by transporters, being therefore a saturable process (During et al., 2002; Anwar et al., 2006; Amiot et al., 2011). Through different mechanisms, that will be detailed onward, once these lipophilic compounds arrive in the enterocyte, they need to be incorporated into chylomicrons, so they can be transported in the blood and to the lymph, both aqueous mediums, ending up in the liver and extrahepatic tissues.

Carotenoids and tocopherols are transported in the core of chylomicrons (Iqbal and Hussain, 2009) but less is known about sterols or triterpenoids. For instance, we reported that oleanolic acid (OA) is transported in plasma bound to albumin, but it cannot be discarded that this triterpene can also be transported in lipoprotein carriers (Rada et al., 2015).

Phytosterols, carotenoids, tocopherols, and triterpenes can exert important biological effects even before arriving at the target tissues. There is evidence that they could modulate triacylglycerol (TAG) hydrolysis by lipoprotein lipase (LPL) in chylomicrons (Cabello-Moruno et al., 2014), which affect their clearance from plasma and liver uptake (Perona et al., 2006), and improve the balance between vasoprotective and prothrombotic factors (Perona et al., 2004). Therefore, they have therapeutic potential to be used against chronic metabolic diseases related to TAG transport and deposition in adipose tissue.

Below, we summarize the current knowledge of the influence of these dietary lipophilic small biomolecules on lipid transport, as well as on the effects they may have on pathophysiological metabolic states related to obesity, insulin resistance and inflammation.

\section{PHYTOSTEROLS}

\section{Definition, Types and Structure}

Phytosterols are bioactive components present in plants that are synthesized via the isoprenoid pathway, while phytostanols are their saturated derivatives. Their main function is to stabilize plant cell membranes and serve as precursors in the synthesis of steroidal saponins, alkaloids, and other steroids (Lai and Akoh, 2005). These plant sterols share structural similarity with cholesterol, differing in a methyl or ethyl group in C24. The most abundant sterols in plants and plant-containing foods are sitosterol $\left(\mathrm{C}_{29} \mathrm{H}_{50} \mathrm{O}\right)$, campesterol $\left(\mathrm{C}_{29} \mathrm{H}_{48} \mathrm{O}\right)$, and stigmasterol $\left(\mathrm{C}_{29} \mathrm{H}_{48} \mathrm{O}\right)$ (Figure 1), accounting for about $90 \%$ of total sterols to the diet (Klingberg et al., 2008).

\section{Dietary Sources and Bioavailability}

The main sources of plant sterols are vegetable oils, nuts and unrefined grains, whereas plant stanols are mainly present in cereals, especially wheat and rye (Valsta et al., 2004). Other important dietary sources are phytosterol-enriched food products, usually in their esterified form, including margarines, yogurts and beverages.

Absorption of phytosterols follows the same pathways as cholesterol in the proximal part of the small intestine. Free sterols are solubilized into the micelle that is formed in the emulsified fat phase. In a group of ten healthy subjects, it was found that phytosterols are absorbed in the brush border membrane of the enterocyte via transporter proteins, such as Niemann-Pick C1Like 1 (NPC1L1) with a very low efficiency ( $<2 \%$ for sterols and $<0.2 \%$ for stanols) compared to cholesterol (Ostlund et al., 2002). Consequently, their serum concentrations are low, varying from 7 to $24 \mathrm{mmol} / \mathrm{L}$ for sterols, and from 0.05 to $0.3 \mathrm{mmol} / \mathrm{L}$ for stanols.

\section{Effects on Lipid Absorption and Transport}

Phytosterols have the ability to modulate serum cholesterol transport and metabolism. The FDA and EFSA have approved health claims for functional foods that provide $1.3 \mathrm{~g}$ (FDA, 2010) or $3.0 \mathrm{~g}$ (EFSA, 2015) of plant sterols/day respectively for reducing serum total cholesterol (TC) and LDL (Brufau et al., 2008; Musa-Veloso et al., 2011). Nevertheless, the clinical relevance of these cholesterol lowering effects is still a matter of controversy (Talati et al., 2010). The impairment in cholesterol absorption by displacement from micelles in the intestinal lumen by phytosterols has been suggested as the underlying mechanism (Amiot et al., 2011), however, there is also evidence that they modify the expression of genes involved in cholesterol reesterification in the enterocyte and its removal via trans-intestinal cholesterol efflux (Gylling and Simonen, 2015).

Phytosterols may likewise contribute to reduce serum TAG (Demonty et al., 2013) by decreasing their intestinal absorption (Rideout et al., 2010), restricting chylomicron assembly in the enterocyte (Liang et al., 2011) and reducing the hepatic release of very-low-density lipoproteins (VLDL) (Gylling and Miettinen, 1994). Reductions in serum TAG levels of $6-20 \%$ by the intake of 1.5-2 g/day of phytosterol/phytostanols have been reported (Sialvera et al., 2012; Demonty et al., 2013; De Smet et al., 2015). However, other studies did not corroborate such changes (Amiot et al., 2011; De Smet et al., 2015).

\section{Implications in Metabolic Diseases}

Metabolic syndrome (MetSyn) is a cluster of several pathophysiological states, including central obesity, hyperglycemia, hypertriacylglycerolemia, hypertension and low HDL, which may increase the risk of type 2 diabetes (T2DM), cardiovascular disease (CVD), neurodegenerative disorders and certain types of cancer (Mottillo et al., 2010). There are data indicating that consumption of phytosterols may have beneficial effects on MetSyn subjects (Rondanelli et al., 2013; Coker et al., 2015), although controversy remains (Ooi et al., 2007). A 16-weeks study in gestational diabetic women taking phytosterol-rich margarine reported an increase in serum HDL and improvements in markers of glucose homeostasis, including fasting glycemia, fasting insulin, HOMA-IR (homeostatic model assessment for insulin resistance) and $\beta$-cell function ( $\mathrm{Li}$ and Xing, 2016). In contrast, a randomized controlled trial (RCT) with 151 T2DM patients taking a low-fat spread enriched in phytosterols ( $2 \mathrm{~g} /$ day) for 6 weeks reported reductions in serum TAG and LDL, but no effects on postprandial glycemia (Trautwein et al., 2018). 

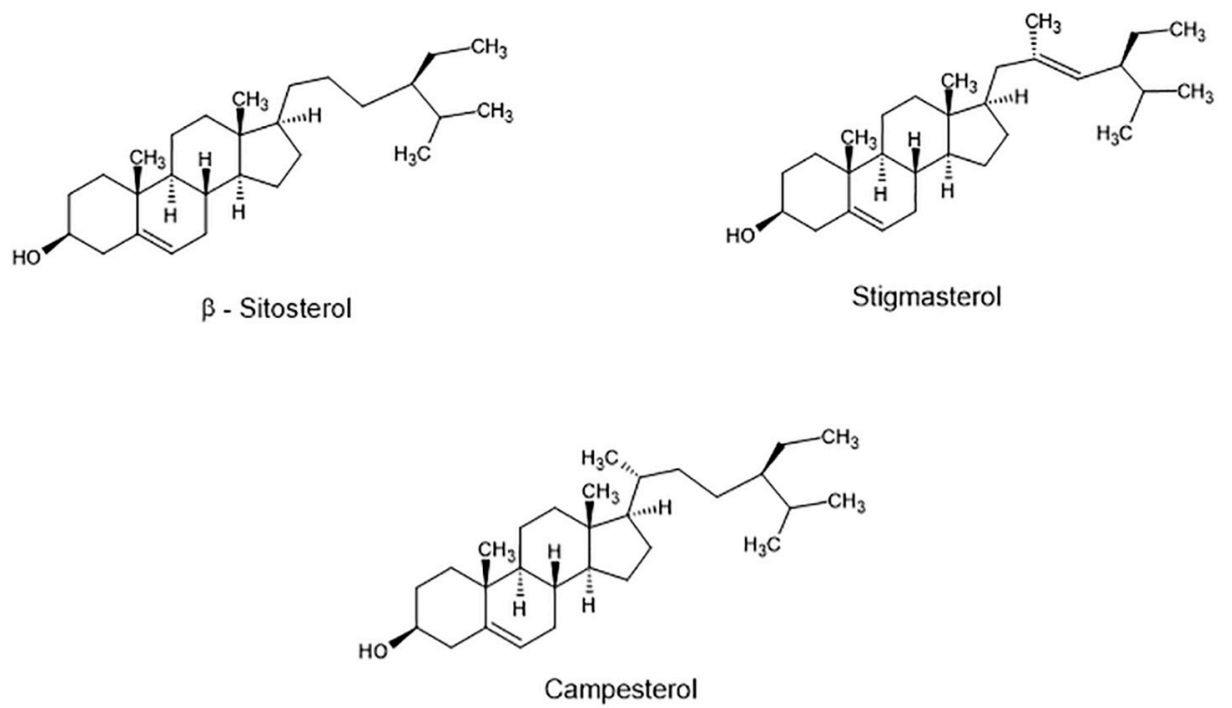

FIGURE 1 | Structure of main phytosterols found in food.

Both in vitro (Kurano et al., 2011; Valerio and Awad, 2011) and in vivo (mice and piglets experimental models) (Hu et al., 2017; Plat et al., 2014) experiments indicate that phytosterols exhibit anti-inflammatory properties. However, systematic reviews and meta-analyses of RCT do not support that the regular intake of phytosterol-enriched foods reduced low-grade systemic inflammation associated to obesity (Rocha et al., 2016).

\section{CAROTENOIDS}

\section{Definition, Types and Structure}

Carotenoids include both carotenes and xanthophylls. They are poly-unsaturated isoprenoids, often consisting of eight isoprene units. Thus, many carotenoids belong to the tetraterpenes. At the ends of the carbon chain various functional groups can be located, resulting in the enormous variety of more than 750 carotenoids known today (Westphal and Böhm, 2015). Carotenes harbor hydrocarbon-type structures (Figure 2), whereas xanthophylls contain oxygen in their molecules (Figure 3). Although more than one thousand carotenoids have been identified (Yabuzaki, 2017), only about 40 are present in human blood and tissues. $\beta$-Carotene $\left(\mathrm{C}_{40} \mathrm{H}_{56}\right)$, $\alpha$-carotene $\left(\mathrm{C}_{40} \mathrm{H}_{56}\right)$, and lycopene $\left(\mathrm{C}_{40} \mathrm{H}_{56}\right)$ are the main carotenes, while lutein $\left(\mathrm{C}_{40} \mathrm{H}_{56} \mathrm{O}_{2}\right)$, zeaxanthin $\left(\mathrm{C}_{40} \mathrm{H}_{56} \mathrm{O}_{2}\right)$, $\beta$-cryptoxanthin $\left(\mathrm{C}_{40} \mathrm{H}_{56} \mathrm{O}\right)$, and astaxanthin $\left(\mathrm{C}_{40} \mathrm{H}_{52} \mathrm{O}_{4}\right)$ are the main xanthophylls (Figure 2).

\section{Dietary Sources and Bioavailability}

$\beta$-carotene shows the greatest capability to be incorporated into mixed micelles, while that of lycopene is very poor (Sy et al., 2012). In fact, and unlike other carotenoids, lycopene levels in plasma and tissues do not correlate well with its dietary intake (Gann, 2005). According to The Carotenoid Content of
US Foods (Holden et al., 1999) and data from O'Neill et al. (2001) the most abundant food sources of carotenoids in the United States and Europe are carrot for $\alpha$ and $\beta$-carotene, tomato and watermelon for lycopene, kale and parsley for lutein, red pepper for zeaxanthin and papaya for $\beta$-cryptoxanthin.

Experiments in Caco-2 cells show that carotenoid uptake is curvilinear, time-dependent, saturable and dose-dependent (During et al., 2002), being facilitated by epithelial transporters with broad substrate specificity (Reboul and Borel, 2011), such as the scavenger receptor B1 (SR-B1) (During et al., 2005). After intestinal absorption, carotenoids are incorporated into chylomicrons, which account for $80 \%$ of total plasma carotenoids in the postprandial period, and transported to the liver, their main storage organ (During et al., 2002).

\section{Effects on Lipid Absorption and Transport}

In rats fed a high-fat diet, lycopene-enriched tomato juice reduced plasma and hepatic TAG (Kim et al., 2012). Moreover, this juice dose-dependently decreased serum TAG, TC and LDL in hypercholesterolemic hamsters (Lee et al., 2015). In humans, the meta-analysis of twelve intervention studies (Ried and Fakler, 2011) pointed out that supplementation with lycopene-rich edible sources ( $\geq 25 \mathrm{mg}$ lycopene/day) reduced LDL by about $10 \%$. However, a more recent meta-analysis (Cheng et al., 2017) reported that tomato supplements successfully reduced LDL, while supplementation with lycopene alone yielded no significant effects. Plasma levels of $\alpha$-carotene, $\beta$-cryptoxanthin, lutein, zeaxanthin, and lycopene, but not $\beta$-carotene, have showed positive correlations with plasma TC concentrations (Amara et al., 2015). Likewise, $\beta$-cryptoxanthin, lutein, zeaxanthin, and lycopene also positively correlated with LDL. $\beta$-Carotene, $\beta$-cryptoxanthin, lutein, and zeaxanthin further did it with HDL. A trial with 670 non-diabetic Mexican-American children 
<smiles>CC1=C(/C=C/C(C)=C/C=C/C(C)=C/C=C/C=C(C)/C=C/C=C(C)/C=C/C2=C(C)CCCC2(C)C)C(C)(C)CCC1</smiles>

$\beta$ - carotene<smiles>CC1=C(/C=C/C(C)=C/C=C/C(C)=C/C=C/C=C(C)/C=C/C=C(C)/C=C/C2=C(C)CCCC2(C)C)C(C)(C)CCC1</smiles>

$\alpha$ - carotene<smiles>CC(C)=C/C=C/C(C)=C/C=C/C(C)=C/C=C/C=C(C)/C=C/C=C(C)/C=C/C=C(\C)CCC=C(C)C</smiles>

Lycopene

FIGURE 2 | Structure of main carotenes found in food.

determined negative correlations of $\alpha-/ \beta$-carotene with TAG and positive associations with HDL (Farook et al., 2017). By contrast, a research associated to the CARET Study (Omenn et al., 1996) showed that the combined administration of $\beta$-carotene and retinyl palmitate to smoker or asbestos-exposed individuals did not produce significant differences in plasma TAG, TC, and LDL when compared with those receiving placebo (Redlich et al., 1999).

The plasma TAG lowering effect of lycopene has been explained by mRNA overexpression of LPL and increased TAG hydrolysis, but also by enhanced hepatic fatty acid $\beta$-oxidation (Martín-Pozuelo et al., 2015).

The most important effect of carotenoids on lipids and proteins is their ability to protect them from oxidation. The daily administration of $280 \mathrm{~mL}$ of tomato juice (containing $32.5 \mathrm{mg}$ of lycopene) to young females for 2 months decreased plasma levels of malondialdehyde (MDA), a maker of lipid peroxidation, in parallel with a reduction in body fat (Li et al., 2015). However, this was an uncontrolled supplementation trial, so results should be taken with caution. Nevertheless, carotenes seem to be worse superoxide radical quenchers than xanthophylls, especially than those containing carbonyls, like canthaxanthin and astaxanthin (Galano et al., 2010).

\section{Implications in Metabolic Diseases}

Different studies have consistently described an inverse association of the carotenoid dietary intake with BMI, insulin resistance, MetSyn and CVD (Czernichow et al., 2009; Sluijs et al., 2009; Chai et al., 2010; Suzuki et al., 2011; Higuchi et al., 2015).
In adipose tissue, carotenoids influence signaling pathways and gene expression which modulate the pro-inflammatory cytokines secretion and the proliferation/differentiation of adipocytes (Sy et al., 2012; Östh et al., 2014). In mice, a $\beta$-carotene-enriched diet decreased body weight, fat mass and adipocyte size, through the PPAR $\alpha$-mediated overexpression of $\beta$-carotene-15, $15^{\prime}$ oxygenase (Amengual et al., 2011). Also in mice, lycopene restricted adipocyte hypertrophy caused by high-fat diets (Fenni et al., 2017).

In MetSyn patients, carotenoid intake correlated with reductions in waist circumference, visceral fat and subcutaneous fat mass (Sluijs et al., 2009). Carotenoid treatments have been also associated with the improvement of insulin signaling. An inverse association between carotenoids and HOMA-IR was established (Suzuki et al., 2011; Farook et al., 2017; Xiao et al., 2019), although this correlation was not conserved in adjusted models for BMI and waist circumference (Amara et al., 2015). The insulin-sensitizing effect of carotenoids has been attributed, at least partially, to their ability to enhance adiponectin secretion by adipose tissue (Amara et al., 2015; Li et al., 2015; GrasaLópez et al., 2016) and to increase the insulin receptor substrate-2 (IRS-2) expression in the liver (Awazawa et al., 2011).

\section{TOCOPHEROLS AND TOCOTRIENOLS}

\section{Definition, Types and Structure}

"Vitamin E" refers to hydroxychromane derivatives with antioxidant activities. The most common forms of vitamin E 
<smiles>CC1=C[C@H](O)CC(C)(C)[C@H]1/C=C/C(C)=C/C=C/C(C)=C/C=C/C=C(C)/C=C/C=C(C)/C=C/C1=C(C)C[C@@H](O)CC1(C)C</smiles>

Lutein<smiles>CC1=C(/C=C/C(C)=C/C=C/C(C)=C/C=C/C=C(C)/C=C/C=C(C)/C=C/C2=C(C)C[C@@H](O)CC2(C)C)C(C)(C)C[C@H](O)C1</smiles>

Zeaxanthin<smiles>CC1=C(/C=C/C(C)=C/C=C/C(C)=C/C=C/C=C(C)/C=C/C=C(C)/C=C/C2=C(C)C[C@@H](O)CC2(C)C)C(C)(C)CCC1</smiles>

$\beta$ - cryptoxanthin<smiles>CC1=C(/C=C/C(C)=C/C=C/C(C)=C/C=C/C=C(C)/C=C/C=C(C)/C=C/C2=C(C)C(=O)[C@@H](O)CC2(C)C)C(C)(C)CC(O)C1=O</smiles>

Astaxanthin

FIGURE 3 | Structure of main xanthophylls found in food.

are tocopherols (TP) and tocotrienols (T3), but there are also tocomonoenols (T1) and marine derived tocopherols (MDT). Usually, vitamin E is generically named "tocopherols." Their basic structure is a chromium ring hydroxylated at position 6 , the methylation of which classifies them into $\alpha, \beta, \gamma$, or $\delta$ forms. Four families are differentiated by differently saturated side chains (Table 1). These vitamers are naturally in all $R$ configuration (Traber and Atkinson, 2007).

\section{Dietary Sources and Bioavailability}

Vitamin E is found in food such as vegetable oils (sunflower, palm, olive, cocoa, safflower, grape seed), soy beans, olives, blueberries, nuts, grains (wheat, rice, barley) and culinary herbs (cloves, cumin) (Aggarwal et al., 2010). When consumed, tocopherols dissolve into the meal lipid phase and are emulsified at the stomach and duodenum as mixed micelles. Micelles are dissociated and tocopherols absorbed by enterocytes in the intestinal brush border, by both passive diffusion and mediated by receptors, such as the scavenger receptor class B type I (SR-BI) (Reboul et al., 2006) NPC1 like intracellular cholesterol transporter 1 (NPC1L1) (Reboul et al., 2012), and CD36 (Goncalves et al., 2014). Only free forms of vitamin E seem to be uptaken, suggesting that esterified forms are hydrolyzed beforehand (Lombardo and Guy, 1980). Once absorbed, tocopherols integrate in chylomicrons, which are first released to the lymph, and subsequently to the bloodstream. A fraction of tocopherols in chylomicrons is captured by extrahepatic tissues (mainly adipose tissue), whereas the rest goes to the liver in remnant chylomicrons. In addition, tocopherols transfers from chylomicrons to HDL (Traber et al., 2019) and from LDL to HDL (Mardones and Rigotti, 2004) so occur. They are important for vitamin E delivery to reproductive tissues (adrenals, ovaries, and testes), lung and brain. In the liver, $\alpha$-tocopherol is specifically bound to $\alpha$-TF transfer protein ( $\alpha$-TTP), which protects it from catabolism, allowing its incorporation into nascent VLDL (Mustacich et al., 2007). The excess of $\alpha$-TF and other vitamers are secreted in bile or metabolized to carboxyethyl-hydroxychroman (CEHC) and later excreted in urine (Schultz et al., 1995). 
TABLE 1 | Common name, structure, and formula of the four vitamin E families.

\begin{tabular}{|c|c|c|c|c|}
\hline Name & Structure of (RRR) - isomer & R1 & R2 & Formula \\
\hline$\alpha$-tocopherol & & $\mathrm{CH}_{3}$ & $\mathrm{CH}_{3}$ & $\mathrm{C}_{29} \mathrm{H}_{50} \mathrm{O}_{2}$ \\
\hline$\beta$-tocopherol & & $\mathrm{CH}_{3}$ & $\mathrm{H}$ & $\mathrm{C}_{28} \mathrm{H}_{48} \mathrm{O}_{2}$ \\
\hline$\gamma$-tocopherol & & $\mathrm{H}$ & $\mathrm{CH}_{3}$ & $\mathrm{C}_{28} \mathrm{H}_{48} \mathrm{O}_{2}$ \\
\hline$\delta$-tocopherol & & $\mathrm{H}$ & $\mathrm{H}$ & $\mathrm{C}_{27} \mathrm{H}_{46} \mathrm{O}_{2}$ \\
\hline$\alpha$-tocotrienol & & $\mathrm{CH}_{3}$ & $\mathrm{CH}_{3}$ & $\mathrm{C}_{29} \mathrm{H}_{44} \mathrm{O}_{2}$ \\
\hline$\beta$-tocotrienol & & $\mathrm{CH}_{3}$ & $\mathrm{CH}_{3}$ & $\mathrm{C}_{28} \mathrm{H}_{42} \mathrm{O}_{2}$ \\
\hline$\gamma$-tocotrienol & & $\mathrm{H}$ & $\mathrm{CH}_{3}$ & $\mathrm{C}_{28} \mathrm{H}_{42} \mathrm{O}_{2}$ \\
\hline$\delta$-tocotrienol & & $\mathrm{H}$ & $\mathrm{H}$ & $\mathrm{C}_{27} \mathrm{H}_{40} \mathrm{O}_{2}$ \\
\hline$\alpha$-tocomonoenol & & $\mathrm{CH}_{3}$ & $\mathrm{CH}_{3}$ & $\mathrm{C}_{29} \mathrm{H}_{48} \mathrm{O}_{2}$ \\
\hline$\beta$-tocomonoenol & & $\mathrm{CH}_{3}$ & $\mathrm{H}$ & $\mathrm{C}_{28} \mathrm{H}_{46} \mathrm{O}_{2}$ \\
\hline$\gamma$-tocomonoenol & & $\mathrm{H}$ & $\mathrm{CH}_{3}$ & $\mathrm{C}_{28} \mathrm{H}_{46} \mathrm{O}_{2}$ \\
\hline$\delta$-tocomonoenol & & $\mathrm{H}$ & $\mathrm{H}$ & $\mathrm{C}_{27} \mathrm{H}_{44} \mathrm{O}_{2}$ \\
\hline$\alpha-M D T$ & & $\mathrm{CH}_{3}$ & $\mathrm{CH}_{3}$ & $\mathrm{C}_{29} \mathrm{H}_{48} \mathrm{O}_{2}$ \\
\hline$\beta-M D T$ & & $\mathrm{CH}_{3}$ & $\mathrm{CH}_{3}$ & $\mathrm{C}_{28} \mathrm{H}_{46} \mathrm{O}_{2}$ \\
\hline$\gamma$-MDT & & $\mathrm{H}$ & $\mathrm{CH}_{3}$ & $\mathrm{C}_{28} \mathrm{H}_{46} \mathrm{O}_{2}$ \\
\hline$\delta-M D T$ & & $\mathrm{H}$ & $\mathrm{H}$ & $\mathrm{C}_{27} \mathrm{H}_{44} \mathrm{O}_{2}$ \\
\hline
\end{tabular}

Dietary lipids are effectors of vitamin E absorption. MUFA and PUFA promoted tocopherols absorption compared to saturated ones in cockerels (Prévéraud et al., 2014) and Caco-2 cells (Failla et al., 2014). Conversely, phosphatidylcholine, vitamin C, carotenoids, and polyphenols significantly impair it in rats (Koo and Noh, 2001; Nishimukai and Hara, 2004; Reboul et al., 2007; Goncalves et al., 2015). There is controversial data about the fat quantity required for optimal vitamin $\mathrm{E}$ absorption (Roodenburg et al., 2000; Bruno et al., 2006). A recent trial with healthy women has determined that $\alpha$-TP absorption is not quantitatively limited by the dietary fat abundance or fasting (Traber et al., 2019). The authors pointed that $\alpha$-TP is retained in the enterocyte until sufficient fat is consumed to promote chylomicron secretion.

\section{Effects on Lipid Absorption and Transport}

$\alpha$-TP diminishes the capture of ox-LDL by monocytes/macrophages through $\mathrm{CD} 36$ downregulation (Ricciarelli et al., 2000; Munteanu et al., 2006).

Analogously, T3 decrease serum NEFA, TAG, TC, LDL, Apo B, glucose and HbA1c levels and hepatic cholesterol (Qureshi et al., 2000; Chou et al., 2009), while increase HDL (Budin et al., 2009; Matough et al., 2014). T3 decline likewise HMG-CoA reductase and hyperlipidemia in murine models of hypercholesterolemia and atherosclerosis (Iqbal et al., 2003; Minhajuddin et al., 2005).

\section{Implications in Metabolic Diseases}

Tocopherols are potent antioxidants within lipid domains, both in vitro (fats and food oils) and in vivo (biological membranes, lipoproteins and tissues) (Kuhad and Chopra, 2009; Siddiqui et al., 2010; Wong et al., 2017). $\alpha$-TP efficiently decreased hydroxyl and superoxide radicals and scavenged peroxides in different animal models (Cachia et al., 1998; Alcalá et al., 2015) and increased NO production (Meydani et al., 2014).
$\gamma$-TP attenuated superoxide, lipid peroxides and ox-LDL in arteries of Sprague Dawley rats (Saldeen et al., 1999). It significantly increased NOS activity and plasma nitrites and also enhanced endogenous SOD and glutathione peroxidase activities in spontaneously hypertensive rats (SHR) (Newaz et al., 2003; Budin et al., 2009; Matough et al., 2014). T3 reduced lipid peroxidation and oxidative stress in murine models (Kuhad and Chopra, 2009; Burdeos et al., 2012) and HepG2 cells (Asai et al., 1999). These antioxidant response is consistent with the vitamin $\mathrm{E}$ role as $\mathrm{Nrf2}$ activator (Bozaykut et al., 2014). In experimental animals, $\alpha$-TP improved hypertriglyceridemia, insulin resistance and hepatic steatosis (Alcalá et al., 2015).

Vitamin E also performs against inflammation; $\alpha$-TP inhibited PKC, 5-LOX and PLA2, and activated PP2A and DAG kinase (Mathur et al., 2015; Hayashi et al., 2017). It repressed the activation of nuclear factor $\kappa \mathrm{B}(\mathrm{NF} \kappa \mathrm{B})$, as well as the biosynthesis of pro-inflammatory cytokines and adhesion molecules (CookMills, 2013; Rashidi et al., 2017). Likewise, $\gamma$-TP blocked COX activity and diminished prostaglandin E2 (PGE2) synthesis (Jiang et al., 2000; Yoshikawa et al., 2005). $\gamma$-T3 inhibited the production of TNF- $\alpha$, transforming growth factor-beta (TGF$\beta$ ), and IL-1 $\beta$ in STZ-diabetic rats. In human adipocytes, $\gamma$-T3 suppressed MAP kinase and $\mathrm{NF \kappa B}$ pathways (Kuhad et al., 2009). In C57BL/6J mice, $\gamma$-T3 improved insulin signaling and glucose tolerance. It also decreased MCP-1 in adipose tissue, indicating a lesser macrophage infiltration (Zhao et al., 2015). Despite these beneficial effects, some authors have suggested that high doses of vitamin E could become harmful. For instance, a dose of $600 \mathrm{mg} \alpha-\mathrm{TP} / \mathrm{kg}$ augmented blood pressure and lipid peroxides in serum and brain tissue of SHR (Miyamoto et al., 2009).

In humans, evidence of vitamin $\mathrm{E}$ effects on metabolic disorders is still not solid. Some trials showed that vitamin E improves dyslipidemia in patients of MetSyn (Devaraj et al., 


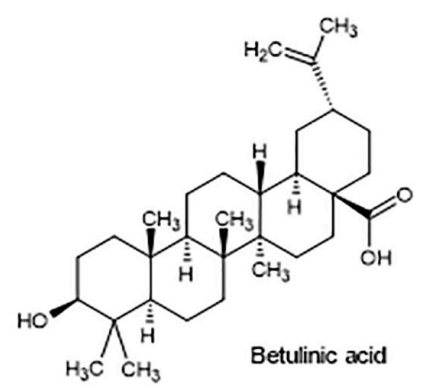<smiles>CCN(C)CC</smiles><smiles>CC1(C)CC[C@]2(C(=O)O)CC[C@]3(C)C(CCC4[C@@]5(C)CC[C@H](O)C(C)(C)C5CC[C@]43C)C2C1</smiles><smiles>CC1(C)CCC2(C(=O)O)CC[C@]3(C)C(=CCC4[C@@]5(C)C[C@H](O)[C@@H](O)C(C)(C)C5CC[C@]43C)C2C1</smiles><smiles>C[C@H]1CCC2(C(=O)O)CC[C@]3(C)C(CCC4[C@]3(C)CC[C@H]3C(C)(C)[C@H](O)CC[C@]43C)C2[C@@H]1C</smiles><smiles>C[C@H]1CCC2(C(=O)O)CC[C@]3(C)C(=CCC4[C@@]5(C)C[C@H](O)[C@@H](O)[C@@](C)(O)[C@@H]5CC[C@]43C)C2[C@@H]1C</smiles>

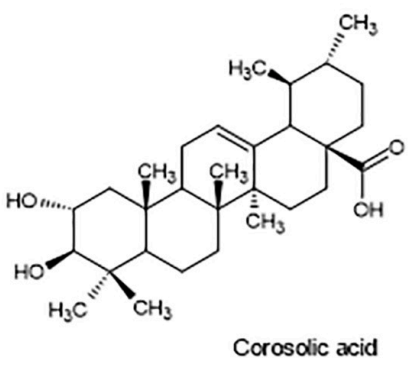

FIGURE 4 | Structure of main bioactive pentacyclic triterpenes of lupine, oleanane and ursane subtypes.

2008; Heng et al., 2015), hypercholesterolemia (Qureshi et al., 2002; Zaiden et al., 2010), or diabetes (Baliarsingh et al., 2005). Furthermore, tocopherols improved glycemic control (Irandoost et al., 2013), hypertension (Jain and Jain, 2012) and increased the endogenous antioxidant capacity (Vafa et al., 2015). In animal models, $\alpha$-TP improves hypertriglyceridemia, insulin resistance and hepatic steatosis (Alcalá et al., 2015). It also reduces LXR $\alpha$ expression and increases ABCA1, preventing cholesterol-mediated damage to cardiomyocytes (Sozen et al., 2018).

Cohort studies and RCT have displayed an inverse association between vitamin $\mathrm{E}$ and the risk of ischemic cardiomyopathy (Venturi et al., 2019), stroke (Boaz et al., 2000), coronary artery disease (Muntwyler et al., 2002), myocardial infarction (Stephens et al., 1996; Boaz et al., 2000) and death due to heart failure (Muntwyler et al., 2002; Eshak et al., 2018).
However, other well-designed trials, such as SU.VI.MAX (Kubota et al., 2011) and PREDIMED (Henríquez-Sánchez et al., 2016), did not determine any relationship between vitamin $\mathrm{E}$ supplementation and CVD incidence and mortality. Neither on circulating lipids (O’byrne et al., 2000; Mustad et al., 2002; Rasool et al., 2006).

\section{PENTACYCLIC TRITERPENES}

\section{Definition, Types and Structure}

Pentacyclic triterpenes (PT) are synthetized, as phytosterols, through the mevalonate pathway and oxidosqualene cyclization. Most frequent PT belong to three subtypes: lupane (betulinic acid), oleanane (uvaol, erythrodiol, oleanolic and maslinic acids) and ursane (ursolic, asiatic, corosolic, and boswellic acids) 


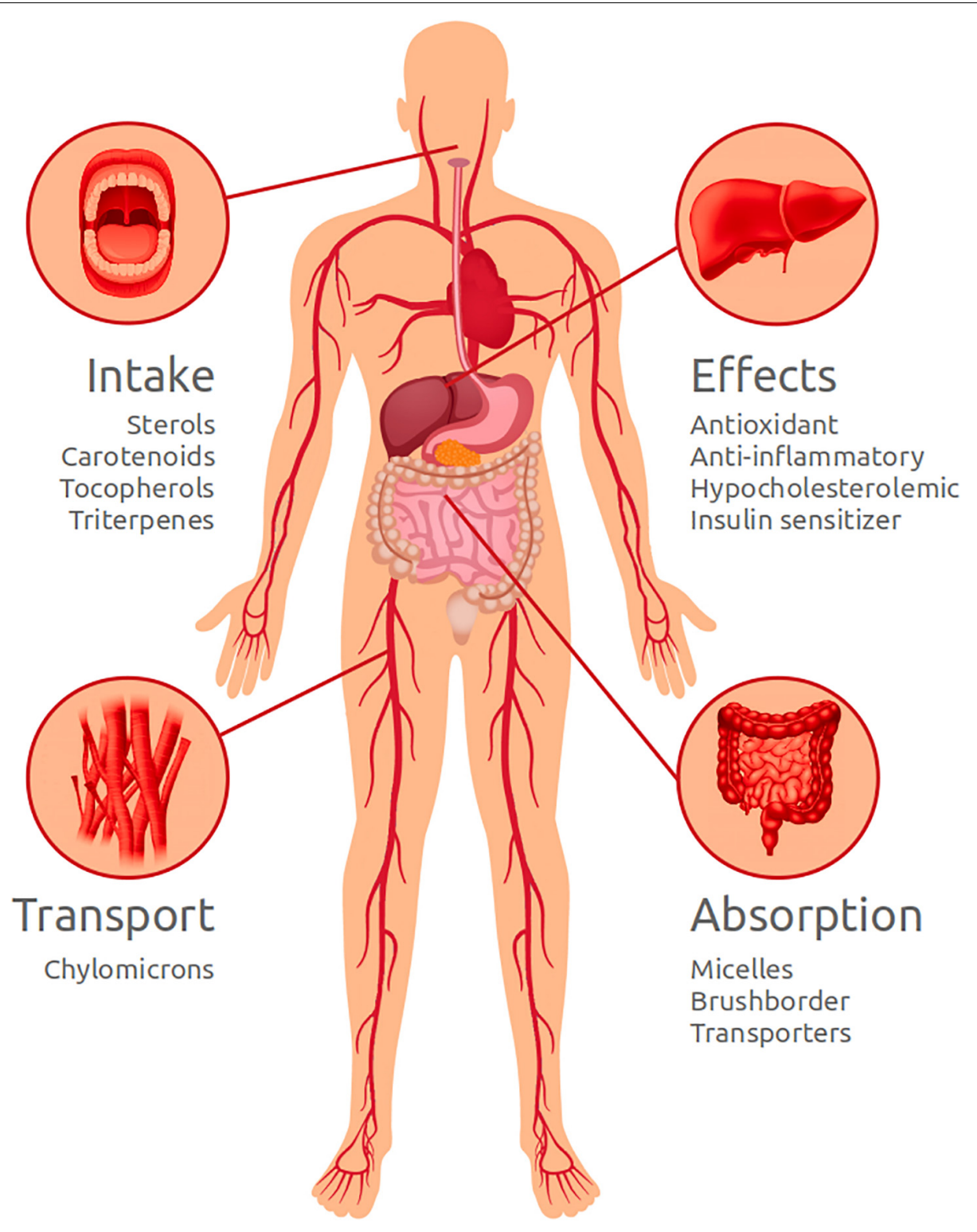

FIGURE 5 | Schematic drawing illustrating the main processes and effects that phytosterol, carotenoids, tocopherols, and triterpenes may have on human body.

(Figure 4). PT can occur as free, acylated (with hydroxycinnamic acids or fatty acids, for instance) or glycosylated (triterpenoid saponins) forms (Furtado et al., 2017).

\section{Dietary Sources and Bioavailability}

Pentacyclic triterpenes are natural components of a great variety of fruits, vegetables, and medicinal plants and are therefore part of the human diet. They are found in apple, pear, mango, green pepper, strawberries, mulberry, guava or olives; but also in aromatic herbs (e.g., basil, oregano, rosemary, and lavender) (Jäger et al., 2009). In vivo studies have shown that PT bioavailability differs when they are administered as pure compounds or in a complex matrix, such as a food item. The presence of fat appears also of major importance, since the solubilization and micellarization of lipophilic compounds are necessary steps prior to absorption (Furtado et al., 2017). Although absorption and metabolism processes are not well established, both passive and $P$-glycoprotein-mediated active transport have been postulated for intestinal absorption of PT (Wang et al., 2017; Jinhua, 2019). They result widely distributed among tissues after passing through the liver (Rada et al., 2011; Zhu et al., 2013).

\section{Effects on Lipid Absorption and Transport}

In animal models of dyslipidemia, PT reduce plasma TAG, TC, LDL, VLDL and NEFA, whereas significantly increase HDL and NO (Wang et al., 2013; Pan et al., 2018), enhance 
plasma leptin and reduce ghrelin (Wang et al., 2013). They downregulate lipogenic genes (ACC, SCD2, GPAT3, ACAT) (Wang et al., 2013) and diminish hepatic fatty acid oxidation by downregulating PPAR- $\gamma$ coactivator-1 $\beta$ (PGC-1 $\beta$ ) (Kuroda et al., 2012). In addition, PT regulate the expression of genes involved in regulation of lipid metabolism, such as PPAR- $\alpha$ (Quang et al., 2011), PPAR- $\gamma$ (Luo et al., 2018), AdipoR1, and AdipoR2 (Sung et al., 2010).

\section{Implications in Metabolic Diseases}

Pentacyclic triterpenes present several other biological activities, including anti-inflammatory, antioxidant, anti-viral, antidiabetic, anti-tumor, hepatoprotective, and cardioprotective, and could be used as anti-ulcer drugs, as well as for the prevention and treatment of metabolic diseases (Reen-Yen et al., 2009; Yamai et al., 2009; de Melo et al., 2010; Jiang et al., 2015; Fernández-Aparicio et al., 2019). As a result, some triterpenes are currently being evaluated in clinical trials (Skarke et al., 2012; Santos-Lozano et al., 2019).

On peripheral tissues, PT improve insulin signaling, upregulating the expression of IR and IRS (Whalley et al., 2011), promoting IR auto-phosphorilation (Sato et al., 2007) and selectively inhibiting tyrosine phosphatases PTP1B and TCPTP (Jung et al., 2007; Teodoro et al., 2008; Genet et al., 2010; Bu et al., 2011). Moreover, PT arise the activity of essential kinases for insulin-stimulated events, such as the PI3K/Akt axis (Galic et al., 2005; Ramírez-Espinosa et al., 2011), ERK 1/2, LKB1, and AMPK (Feng et al., 2011). In the liver, PT inhibit GSK3 $\beta$ (Sangeetha et al., 2010; Zeng et al., 2012; Ramírez-Espinosa et al., 2011) and potentiate the glycogen pool through the stimulation of glucokinase activity and the repression of glucose-6-phosphatase and glycogen phosphorylase (Ha et al., 2009; Azevedo et al., 2010; Saha et al., 2010). Another hypoglycemic effect of PT is their ability to strongly inhibit intestinal and pancreatic $\alpha$-glucosidases (Ali et al., 2002; Castellano et al., 2016). Likewise, PT markedly reduce microvesicular steatosis and lipid droplets in the liver (Woo et al., 2006).

PT inhibit the polyol pathway and attenuate the synthesis of advanced glycation end-products (AGEs). They inhibit aldose reductase and sorbitol dehydrogenase (Cheng et al., 2010), and enhance glyoxalase-I. In rodent, they reduce the formation of methylglyoxal, pentosidine, $N \varepsilon$-(carboxymethyl)lysine (Ahn et al., 2017), plasma HbAlc and urinary glycated albumin (Bachhav et al., 2015).

Although modest radical scavengers (Li et al., 2014; Wang et al., 2015; Castellano et al., 2016; Lee et al., 2016), PT strongly potentiate the adaptive cell response against oxidative and chemotoxic stresses. They stimulate the expression of antioxidant and NADPH-producing enzymes (Djeziri et al., 2018; Gamede et al., 2018; Su et al., 2018), and reduce LDH and MDA productions (Djeziri et al., 2018). In these effects, the activation of the nuclear factor Nrf2 seems to play a key role (Yin and Chan, 2007; Allouche et al., 2011; Castellano et al., 2013).

Furthermore, PT block NFאB activation (Belleza et al., 2010; Castellano et al., 2013), and irreversibly inhibit phospholipase A2 (Dharmappa et al., 2009), attenuating the production of proinflammatory cytokines (Du and Ko, 2006; Yang et al., 2007;
Tsai and Yin, 2008). PT enhance the levels of angiotensin 1-7, NO and eNOS (Soobrattee et al., 2005). In experimental animals, PT decrease hepatic and adipose tissue productions of ROS, IL1b, IL-6, IL-18, and TNF $\alpha$ (Huang et al., 2005; Chen et al., 2006, 2017; Wang et al., 2010; Saaby et al., 2011), together with the inhibition of NLRP3 inflammasome and caspase-1 pathways (Wang et al., 2010).

At $\beta$-cell level, PT increase the glucose-stimulated insulin biosynthesis and secretion through a multifactorial mechanism. They stimulate pro-insulin gene expression (Gilon and Henquin, 2001), activate M3-subtype muscarinic receptors (Ali et al., 2002), and perform as selective agonists of TGR5 receptors (Genet et al., 2010). PT act likewise as anti-apoptotic agents and selective enhancers of the Shp-2 phosphatase activity (Ali et al., 2006).

\section{CONCLUDING REMARKS}

Sterols, carotenoids, tocopherols, and pentacyclic triterpenoids are all dietary lipophilic biomolecules with important functional effects for human health. These molecules are solubilized in meal fats and emulsified into mixed micelles in the intestinal lumen, before been taken-up by enterocytes and poured into the bloodstream into chylomicrons. Figure 5 illustrates the main processes and effects that phytosterol, carotenoids, tocopherols, and triterpenes may have on human body.

Although structurally diverse, they share, with different intensity, antioxidant and anti-inflammatory features. By attenuating oxidative stress and inflammation, they improve disorders associated to obesity and dyslipidemia. In animal models and human trials these functional ingredients have demonstrated to decrease plasma levels of TAG, TC, and LDL, whereas arise the leptin, adiponectin and HDL concentrations. They ameliorate hepatic steatosis, protect lipids from oxidation and reduce LDH and MDA productions. These compounds amend BMI, as well as abdominal and subcutaneous obesity.

Furthermore, carotenoids, vitamin E and PT may act as insulin-sensitizers, improving insulin resistance and pathological disorders related to MetSyn. Notoriously, PT also preserve functionality and survival of pancreatic $\beta$-cell, increasing the insulin release capability. Vitamin $\mathrm{E}$ is a potent lipophilic antioxidant, which scavenge hydroxyl and superoxide radicals and reduce the production of lipid peroxides. PT, by contrast, are modest radical scavengers, but potent enhancers of the adaptive cell response against oxidative and chemotoxic stress. Part of the effects of both tocopherols and PT can be explained by its capability to activate Nrf2 and the expression of phase 2 genes. Through Nrf-2 activation, they upregulate the expression of antioxidant enzymes and lipogenic genes. On the other hand, tocopherols and PT are able to inhibit the transactivation of NFKB, inhibiting the inflammatory response. They repress the production of pro-inflammatory cytokines, the expression of adhesion molecules, and a number of inflammatory pathways, including MAPK, LOX, or COX.

The pharmacological activity of these small lipophilic molecules has been correlated with lower risks to develop T2DM, CVD, and other pathological complications of MetSyn. 
Unfortunately, accumulated evidence in humans is still limited, and more well-designed RCT should be performed before nutritional recommendations may be directed to general population.

\section{REFERENCES}

Aggarwal, B. B., Sundaram, C., Prasad, S., and Kannappan, R. (2010). Tocotrienols, the Vitamin E of the 21st Century: its potential against cancer and other chronic diseases. Biochem. Pharmacol. 80, 1613-1631. doi: 10.1016/j.bcp.2010.07.043

Ahn, Y. M., Choi, Y. H., Yoon, J. J., Lee, Y. J., Cho, K. W., Kang, D. G., et al. (2017). Oleanolic acid modulates the renin-angiotensin system and cardiac natriuretic hormone concomitantly with volume and pressure balance in rats. Eur. J. Pharmacol. 809, 231-241. doi: 10.1016/j.ejphar.2017.05.030

Alcalá, M., Sánchez-Vera, I., Sevillano, J., Herrero, L., Serra, D., Ramos, M. P., et al. (2015). Vitamin E reduces adipose tissue fibrosis, inflammation, and oxidative stress and improves metabolic profile in obesity. Obesity 23, 1598-1606. doi: 10.1002/oby. 21135

Ali, H., Houghton, P. J., and Soumyanath, A. (2006). $\alpha$-amylase inhibitory activity of some malaysian plants used to treat diabetes; with particular reference to phyllanthus amarus. J. Ethnopharmacol. 107, 449-455. doi: 10.1016/j.jep.2006. 04.004

Ali, M. S., Ahmar Jahangir, M., Shazad-ul-Hussam, S., and Iqbal Choudhary, M. (2002). Inhibition of $\alpha$-glucosidase by oleanolic acid and its synthetic derivatives. Phytochemistry 60, 295-299. doi: 10.1016/s0031-9422(02)00104-8

Allouche, Y., Warleta, F., Campos, M., Sánchez-Quesada, C., Uceda, M., Beltrán, G., et al. (2011). Antioxidant, antiproliferative, and pro-apoptotic capacities of pentacyclic triterpenes found in the skin of olives on MCF-7 human breast cancer cells and their effects on DNA damage. J. Agric. Food Chem. 59, 121-130. doi: $10.1021 /$ jf102319y

Amara, B., Tourniaire, N. F., Maraninchi, M., Attia, N., Amiot-Carlin, M. J., and Raccah, D. (2015). Independent positive association of plasma $\beta$-carotene concentrations with adiponectin among non-diabetic obese Subjects. Eur. J. Nutr. 54, 447-454. doi: 10.1007/s00394-014-0728-6

Amengual, J., Gouranton, E., van Helden, Y. G. J., Hessel, S., Ribot, J., Kramer, E., et al. (2011). Beta-carotene reduces body adiposity of mice via BCMO1. PLoS One 6:e0020644. doi: 10.371/journal.pone.0020644

Amiot, M. J., Knol, D., Cardinault, N., Nowicki, M., Bott, R., Antona, C., et al. (2011). Phytosterol ester processing in the small intestine: impact on cholesterol availability for absorption and chylomicron cholesterol incorporation in healthy humans. J. Lipid Res. 52, 1256-1264. doi: 10.1194/jlr.M013730

Anwar, K., Kayden, H. J., and Hussain, M. M. (2006). Transport of vitamin E by differentiated Caco-2 Cells. J. Lipid Res. 47, 1261-1273. doi: 10.1194/jlr. M500523-JLR200

Asai, A., Nakagawa, K., and Miyazawa, T. (1999). Antioxidative effects of turmeric, rosemary and capsicum extracts on membrane phospholipid peroxidation and liver lipid metabolism in mice. Biosci. Biotechnol. Biochem. 63, 2118-2122. doi: 10.1271/bbb.63.2118

Awazawa, M., Ueki, K., Inabe, K., Yamauchi, T., Kubota, N., Kaneko, K., et al. (2011). Adiponectin enhances insulin sensitivity by increasing hepatic IRS-2 expression via a macrophage-derived IL-6-dependent pathway. Cell Metab. 13, 401-412. doi: 10.1016/j.cmet.2011.02.010

Azevedo, M. F., Camsari, Ç, Sá, C. M., Lima, C. F., Fernandes-Ferreira, M., and Pereira-Wilson, C. (2010). Ursolic acid and luteolin-7-glucoside improve lipid profiles and increase liver glycogen content through glycogen synthase kinase-3. Phytother. Res. 24(Suppl. 2), 220-224. doi: 10.1002/Ptr.3118

Bachhav, S. S., Bhutada, M. S., Patil, S. P., Sharma, K. S., and Patil, S. D. (2015). Oleanolic acid prevents increase in blood pressure and nephrotoxicity in nitric oxide dependent type of hypertension in rats. Pharmacog. Res. 7, 385-392. doi: 10.4103/0974-8490.159575

Baliarsingh, S., Beg, Z. H., and Ahmad, J. (2005). The therapeutic impacts of tocotrienols in type 2 diabetic patients with hyperlipidemia. Atherosclerosis 182, 367-374. doi: 10.1016/j.atherosclerosis.2005.02.020

Belleza, I., Mierla, A. L., and Minelli, A. (2010). Nrf2 and NF- $\kappa$ B and their concerted modulation in cancer pathogenesis and progression. Cancers 2, 483-497. doi: $10.3390 /$ cancers 2020483

\section{AUTHOR CONTRIBUTIONS}

All the authors listed have contributed equally, directly and intellectually to the work, and have approved it for publication.

Boaz, M., Smetana, T., Weinstein, Z., Matas, U., Gafter, A., Iaina, A., et al. (2000). Secondary prevention with antioxidants of cardiovascular disease in endstage renal disease (SPACE): randomised placebo-controlled trial. Lancet 356, 1213-1218. doi: 10.1016/s0140-6736(00)02783-5

Bozaykut, P., Sozen, E., Yazgan, B., Karademir, B., and Kartal-Ozer, N. (2014). The role of hypercholesterolemic diet and vitamin E on Nrf2 pathway, endoplasmic reticulum stress and proteasome activity. Free Radical Biol. Med. 75:S24. doi: 10.1016/j.freeradbiomed.2014.10.742

Brufau, G., Canela, M. A., and Rafecas, M. (2008). Phytosterols: physiologic and metabolic aspects related to cholesterol-lowering properties. Nutr. Res. 28, 217-225. doi: 10.1016/j.nutres.2008.02.003

Bruno, R. S., Leonard, S. W., Il Park, S., Zhao, Y., and Traber, M. G. (2006). Human vitamin e requirements assessed with the use of apples fortified with deuterium-labeled $\alpha$-tocopheryl acetate. Am. J. Clin. Nutr. 83, 299-304. doi: 10.1093/ajcn/83.2.299

Bu, Y., Shi, T., Meng, M., Kong, G., Tian, Y., Chen, Q., et al. (2011). A Novel screening model for the molecular drug for diabetes and obesity based on tyrosine phosphatase Shp2. Bioorg. Med. Chem. Lett. 21, 874-878. doi: 10.1016/ j.bmcl.2010.11.049

Budin, S. B., Othman, F., Raj Louis, S., Abu Bakar, M., Das, S., and Jamaludin, M. (2009). The effects of palm oil tocotrienol-rich fraction supplementation on biochemical parameters, oxidative stress and the vascular wall of streptozotocin-induced diabetic rats. Clinics 64, 235-244. doi: 10.1590/S180759322009000300015

Burdeos, G. C., Nakagawa, K., Kimura, F., and Miyazawa, T. (2012). Tocotrienol attenuates triglyceride accumulation in HepG2 Cells and F344 rats. Lipids 47, 471-481. doi: 10.1007/s11745-012-3659-0

Cabello-Moruno, R., Martinez-Force, E., Montero, E., and Sánchez Perona, J. (2014). Minor components of olive oil facilitate the triglyceride clearance from postprandial lipoproteins in a polarity-dependent manner in healthy men. Nutr. Res. 34, 40-47. doi: 10.1016/j.nutres.2013.10.003

Cachia, O., El Benna, J., Pedruzzi, E., Descomps, B., Gougerot-Pocidalo, M. A., and Leger, C. L. (1998). $\alpha$-Tocopherol inhibits the respiratory burst in human monocytes: attenuation of P47(Phox) membrane translocation and phosphorylation. J. Biol. Chem. 273, 32801-32805. doi: 10.1074/jbc.273.49. 32801

Castellano, J. M., Guinda, A., Delgado, T., Rada, M., and Cayuela, J. A. (2013). Biochemical basis of the antidiabetic activity of oleanolic acid and related pentacyclic triterpenes. Diabetes 62, 1791-1799. doi: $10.2337 / \mathrm{db} 12$ 1215

Castellano, J. M., Guinda, Á., Macías, L., Santos-Lozano, J. M., Lapetra, J., and Rada, M. (2016). Free radical scavenging and $\alpha$-glucosidase inhibition, two potential mechanisms involved in the antidiabetic activity of oleanolic acid. Grasas y Aceites 67:e142. doi: 10.3989/gya.1237153

Chai, W., Conroy, S. M., Maskarinec, G., Franke, A. A., Pagano, I. S., and Cooney, R. V. (2010). Associations between obesity and serum lipid-soluble micronutrients among premenopausal women. Nutr. Res. 30, 227-232. doi: 10.1016/j.nutres.2010.04.006

Chen, J., Liu, J., Zhang, L., Wu, G., Hua, W., Wu, X., et al. (2006). Pentacyclic triterpenes. part 3: synthesis and biological evaluation of oleanolic acid derivatives as novel inhibitors of glycogen phosphorylase. Bioorg. Med. Chem. Lett. 16, 2915-2919. doi: 10.1016/j.bmcl.2006. 03.009

Chen, S., Wen, X., Zhang, W., Wang, C., Liu, J., and Liu, C. (2017). Hypolipidemic effect of oleanolic acid is mediated by the MiR-98-5p/PGC-1 $\beta$ axis in highfat diet-induced hyperlipidemic mice. FASEB J. 31, 1085-1096. doi: 10.1096/ fj.201601022R

Cheng, H. M., Koutsidis, G., Lodge, J. K., Ashor, A., Siervo, M., and Lara, J. (2017). Tomato and lycopene supplementation and cardiovascular risk factors: a systematic review and meta-analysis. Atherosclerosis 257, 100-108. doi: 10. 1016/j.atherosclerosis.2017.01.009 
Cheng, K., Liu, J., Sun, H., and Xie, J. (2010). Synthesis of oleanolic acid dimers as inhibitors of glycogen phosphorylase. Chem. Biodiv. 7, 690-697. doi: 10.1002/ cbdv.200900086

Chou, T. W., Ma, C. Y., Hsien Cheng, H., Yen Chen, Y., and Hoang Lai, M. (2009). A rice bran oil diet improves lipid abnormalities and suppress hyperinsulinemic responses in rats with Streptozotocin/Nicotinamide-Induced Type 2 Diabetes. J. Clin. Biochem. Nutr. 45, 29-36. doi: 10.3164/jcbn.08-257

Coker, R. H., Deutz, N. E., Schutzler, S., Beggs, M., Miller, S., Wolfe, R. R., et al. (2015). Nutritional supplementation with essential amino acids and phytosterols may reduce risk for metabolic syndrome and cardiovascular disease in overweight individuals with mild hyperlipidemia. J. Endocrinol. Diabet. Obes. 3:1069.

Cook-Mills, J. M. (2013). Isoforms of vitamin E differentially regulate pkc $\alpha$ and inflammation: a review. J. Clin. Cell. Immunol. 04, 348-366. doi: 10.4172/21559899.1000137

Czernichow, S., Vergnaud, A. C., Galan, P., Arnaud, J., Favier, A., Faure, H., et al. (2009). Effects of long-term antioxidant supplementation and association of serum antioxidant concentrations with risk of metabolic syndrome in adults. Am. J. Clin. Nutr. 90, 329-335. doi: 10.3945/ajen.2009.27635

de Melo, C. L., Queiroz, M. G., Fonseca, S. G., Bizerra, A. M., Lemos, T. L., Melo, T. S., et al. (2010). Oleanolic acid, a natural triterpenoid improves blood glucose tolerance in normal mice and ameliorates visceral obesity in mice fed a high-fat diet. Chem. Biol. Interact. 185, 59-65. doi: 10.1016/j.cbi.2010.02.028

De Smet, E., Mensink, R. P., Lütjohann, D., and Plat, J. (2015). Acute effects of plant stanol esters on postprandial metabolism and its relation with changes in serum lipids after chronic intake. Eur. J. Clin. Nutr. 69, 127-133. doi: 10.1038/ ejcn.2014.200

Demonty, T. I, Ras, R., Van Der Knaap, H. C. M., Meijer, L., Zock, P. L., Geleijnse, J. M., et al. (2013). The effect of plant sterols on serum triglyceride concentrations is dependent on baseline concentrations: a pooled analysis of 12 randomised controlled trials. Eur. J. Nutr. 52, 153-160. doi: 10.1007/s00394011-0297-x

Devaraj, S., Leonard, S., Traber, M. G., and Jialal, I. (2008). Gamma-tocopherol supplementation alone and in combination with alpha-tocopherol alters biomarkers of oxidative stress and inflammation in subjects with metabolic syndrome. Free Radical Biol. Med. 44, 1203-1208. doi: 10.1016/j.freeradbiomed. 2007.12.018

Dharmappa, K. K., Kumar, R. V., Nataraju, A., Mohamed, R., Shivaprasad, H. V., and Vishwanath, B. S. (2009). Anti-inflammatory activity of oleanolic acid by inhibition of secretory phospholipase $\mathrm{A}_{2}$. Planta Med. 75, 211-215. doi: 10.1055/s-0028-1088374

Djeziri, F. Z., Belarbi, M., Murtaza, B., Hichami, A., Benammar, C., and Akhtar Khan, N. (2018). Oleanolic acid improves diet-induced obesity by modulating fat preference and inflammation in mice. Biochimie 152, 110-120. doi: 10.1016/ j.biochi.2018.06.025

Du, Y., and Ko, M. K. (2006). Oleanolic acid protects against myocardial ischemiareperfusion injury by enhancing mitochondrial antioxidant mechanism mediated by glutathione and $\alpha$-tocopherol in rats. Planta Med. 72, 222-227. doi: $10.1055 /$ s-2005-916197

During, A., Dawson, H. D., and Harrison, E. H. (2005). Carotenoid transport is decreased and expression of the lipid transporters SR-BI, NPC1L1, and ABCA1 is downregulated in Caco-2 cells treated with ezetimibe. J. Nutr. 135, 2305-2312.

During, A., Hussain, M. M., Morel, D. W., and Harrison, E. H. (2002). Carotenoid uptake and secretion by CaCo- 2 cells: $\beta$-Carotene isomer selectivity and carotenoid interactions. J. Lipid Res. 43, 1086-1095. doi: 10.1194/jlr.m200068jlr200

EFSA (2015). Scientific opinion on dietary reference values for vitamin $\mathrm{E}$ as $\alpha$-Tocopherol. EFSA J. 13, 1-72. doi: 10.2903/j.efsa.2015.4149

Eshak, E. S., Iso, H., Yamagishi, K., Cui, R., and Tamakoshi, A. (2018). Dietary intakes of fat soluble vitamins as predictors of mortality from heart failure in a large prospective cohort study. Nutrition 47, 50-55. doi: 10.1016/j.nut.2017. 09.009

Failla, M. L., Chitchumronchokchai, C., Ferruzzi, M. G., Goltz, S. R., and Campbell, W. W. (2014). Unsaturated fatty acids promote bioaccessibility and basolateral secretion of carotenoids and $\alpha$-Tocopherol by Caco-2 Cells. Food Funct. 5, 1101-1112. doi: 10.1039/c3fo60599j
Farook, V. S., Reddivari, L., Mummidi, S., Puppala, S., Arya, R., Lopez-Alvarenga, J. C., et al. (2017). Genetics of serum carotenoid concentrations and their correlation with obesity-related traits in mexican american children. Am. J. Clin. Nutr. 106, 52-58. doi: 10.3945/ajcn.116.144006

FDA (2010). 76526. Federal Reg. 75, 76526-76571.

Feng, J., Zhang, P., Chen, X., and He, G. (2011). PI3K and ERK/Nrf2 pathways are involved in oleanolic acid-induced heme oxygenase-1 expression in rat vascular smooth muscle cells. J. Cell. Biochem. 112, 1524-1531. doi: 10.1002/jcb. 23065

Fenni, S., Hammou, H., Astier, J., Bonnet, L., Karkeni, E., Couturier, C., et al. (2017). Lycopene and tomato powder supplementation similarly inhibit high-fat diet induced obesity, inflammatory response, and associated metabolic disorders. Mol. Nutr. Food Res. 61, 1-29. doi: 10.1002/mnfr.201601083

Fernández-Aparicio, A., Schmidt-RioValle, J., Perona, J. S., Correa-Rodríguez, M., Castellano, J. M., and González-Jiménez, E. (2019). Potential protective effect of oleanolic acid on the components of metabolic syndrome: a systematic review. J. Clin. Med. 8:1294. doi: 10.3390/jcm8091294

Furtado, N. A. J. C., Pirson, L., Edelberg, H., Miranda, L. M., LoiraPastoriza, C., Preat, V., et al. (2017). Pentacyclic triterpene bioavailability: an overview of in vitro and in vivo studies. Molecules 22, 1-24. doi: 10.3390/ molecules 22030400

Galano, A., Vargas, R., and Martínez, A. (2010). Carotenoids can act as antioxidants by oxidizing the superoxide radical anion. Phys. Chem. Chem. Phys. 12, 193200. doi: 10.1039/b917636e

Galic, S., Hauser, C., Kahn, B. B., Haj, F. G., Neel, B. G., Tonks, N. K., et al. (2005). Coordinated regulation of insulin signaling by the protein tyrosine phosphatases PTP1B and TCPTP. Mol. Cell. Biol. 25, 819-829. doi: 10.1128/ MCB.25.2.819-829.2005

Gamede, M., Mabuza, L., Ngubane, P., and Khathi, A. (2018). The effects of plant-derived oleanolic acid on selected parameters of glucose homeostasis in a diet-induced pre-diabetic rat model. Molecules 23, 1-11. doi: 10.3390/ molecules23040794

Gann, P. H. (2005). Intermediate biomarkers of lycopene/tomato effects in highrisk prostatic tissue. J. Nutr. 135, 2065S-2067S. doi: 10.1093/jn/135.8.2065S

Genet, C., Strehle, A., Schmidt, C., Boudjelal, G., Lobstein, A., Schoonjans, K., et al. (2010). Structure - activity relationship study of betulinic acid, a novel and selective TGR5 agonist, and its synthetic derivatives: potential impact in diabetes. J. Med. Chem. 53, 178-190. doi: 10.1021/jm900872z

Gilon, P., and Henquin, J. C. (2001). Mechanisms and physiological significance of the cholinergic control of pancreatic $\beta$-Cell function. Endoc. Rev. 22, 565-604. doi: 10.1210/edrv.22.5.0440

Goncalves, A., Roi, S., Nowicki, M., Dhaussy, A., Huertas, A., Amiot, M. J., et al. (2015). Fat-soluble vitamin intestinal absorption: absorption sites in the intestine and interactions for absorption. Food Chem. 172, 155-160. doi: 10. 1016/j.foodchem.2014.09.021

Goncalves, A., Roi, S., Nowicki, M., Niot, I., and Reboul, E. (2014). Clusterdeterminant 36 (CD36) impacts on vitamin E postprandial response. Mol. Nutr. Food Res. 58, 2297-2306. doi: 10.1002/mnfr.201400339

Grasa-López, A., Miliar-García, A., Quevedo-Corona, L., Paniagua-Castro, N., Escalona-Cardoso, G., Reyes-Maldonado, E., et al. (2016). Undaria pinnatifida and fucoxanthin ameliorate lipogenesis and markers of both inflammation and cardiovascular dysfunction in an animal model of diet-induced obesity. Mar. Drugs 14:148. doi: 10.3390/md14080148

Gylling, H., and Miettinen, T. A. (1994). Serum cholesterol and cholesterol and lipoprotein metabolism in hypercholesterolaemic NIDDM patients before and during sitostanol ester-margarine treatment. Diabetologia 37, 773-780.

Gylling, H., and Simonen, P. (2015). Phytosterols, phytostanols, and lipoprotein metabolism. Nutrients 7, 7965-7977. doi: 10.3390/nu7095374

Ha, D. T., Trong Tuan, D., Bich Thu, N., Xuan Nhiem, N., Minh Ngoc, T., Hui Yim, N., et al. (2009). Palbinone and triterpenes from moutan cortex (Paeonia Suffruticosa, Paeoniaceae) stimulate glucose uptake and glycogen synthesis via activation of AMPK in insulin-resistant human HepG2 cells. Bioorg. Med. Chem. Lett. 19, 5556-5559. doi: 10.1016/j.bmcl.2009.08.048

Hayashi, D., Yagi, K., Song, C., Ueda, S., Yamanoue, M., Topham, M., et al. (2017). Diacylglycerol kinase alpha is involved in the vitamin e-induced amelioration of diabetic nephropathy in mice. Sci. Rep. 7, $1-8$. 
Heng, K. S., Hejar, A. R., Johnson Stanslas, J., Ooi, C. F., and Loh, S. F. (2015). Potential of mixed tocotrienol supplementation to reduce cholesterol and cytokines level in adults with metabolic syndrome. Malays. J. Nutr. 21, 231-243.

Henríquez-Sánchez, P., Sánchez-Villegas, A., Ruano-Rodríguez, C., Gea, A., Lamuela-Raventós, R. M., Estruch, R., et al. (2016). Dietary total antioxidant capacity and mortality in the PREDIMED study. Eur. J. Nutr. 55, 227-236. doi: 10.1007/s00394-015-0840-2

Higuchi, K., Saito, I., Maruyama, K., Eguchi, E., Mori, H., and Tanno, S. (2015). Associations of serum $\beta$-Carotene and retinol concentrations with insulin resistance: the toon health study. Nutrition 31, 975-980. doi: 10.1016/j.nut.2015. 02.015

Holden, J. M., Eldridge, A. L., Beecher, G. R., Buzzard, I. M., Bhagwat, S. A., Davis, C. S., et al. (1999). Carotenoid content of U.S. Foods: an update of the database. J. Food Compos. Anal. 12, 169-196. doi: 10.1006/jfca.1999.0827

Hu, Q., Zhuo, Z., Fang, S., Zhang, Y., and Feng, J. (2017). Phytosterols improve immunity and exert anti-inflammatory activity in weaned piglets. J. Sci. Food Agric. 97, 4103-4109. doi: 10.1002/jsfa.8277

Huang, T. H. W., Yang, Q., Harada, M., Li, G. Q., Yamahara, J. D., Roufogalis, B., et al. (2005). Pomegranate flower extract diminishes cardiac fibrosis in zucker diabetic fatty rats: modulation of cardiac endothelin-1 and nuclear FactorKappaB pathways. J. Cardiovasc. Pharmacol. 46, 856-862. doi: 10.1097/01.fjc. $0000190489.85058 .7 \mathrm{e}$

Iqbal, J., and Hussain, M. M. (2009). Intestinal Lipid Absorption. Am. J. Physiol. Endocrinol. Metab. 296, 1-22. doi: 10.1152/ajpendo.90899.2008

Iqbal, J., Minhajuddin, M., and Beg, Z. H. (2003). Suppression of 7,12-Dimethylbenz $[\alpha]$ Anthracene-Induced Carcinogenesis and hypercholesterolaemia in rats by tocotrienol-rich fraction isolated from rice bran oil. Eur. J. Cancer Prevent. 12, 447-453. doi: 10.1097/01.cej.0000102802. $33147.4 \mathrm{~b}$

Irandoost, P., Ebrahimi-Mameghani, M., and Pirouzpanah, S. (2013). Does grape seed oil improve inflammation and insulin resistance in overweight or obese women Int. J. Food Sci. Nutr. 64, 706-710. doi: 10.3109/09637486.2013.775228

Jäger, S., Trojan, H., Kopp, T., Laszczyk, M. N., and Scheffler, A. (2009). Pentacyclic triterpene distribution in various plants - rich sources for a new group of multi-potent plant extracts. Molecules 14, 2016-2031.

Jain, A. B., and Jain, A. V. (2012). Vitamin E, its beneficial role in diabetes mellitus (DM) and its complications. J. Clin. Diagnost. Res. 6, 1624-1628. doi: 10.7860/ JCDR/2012/4791.2625

Jiang, Q., Elson-Schwab, I., Courtemanche, C., and Ames, B. N. (2000). $\gamma$ tocopherol and its major metabolite, in contrast to $\alpha$-tocopherol, inhibit cyclooxygenase activity in macrophages and epithelial cells. Proc. Natl. Acad. Sci. U.S.A. 97, 11494-11499. doi: 10.1073/pnas.200357097

Jiang, Q., Wang, D., Han, Y., Han, Z., Zhong, W., and Wang, C. (2015). Modulation of Oxidized-LDL Receptor-1 (LOX1) contributes to the antiatherosclerosis effect of oleanolic acid. Int. J. Biochem Cell Biol. 69, 142-152. doi: 10.1016/j. biocel.2015.10.023

Jinhua, W. (2019). Ursolic acid: pharmacokinetics process in vitro and in vivo, a mini review. Arch. Pharm. 352, 1-5. doi: 10.1002/ardp.201800222

Jung, S. H., Ha, Y. J., Shim, E. K., Choi, S. Y., Jin, J. L., Yun-Choi, H. S., et al. (2007). Insulin-mimetic and insulin-sensitizing activities of a pentacyclic triterpenoid insulin receptor activator. Biochemi. J. 403, 243-250. doi: 10.1042/BJ20061123

Kim, A. Y., Jin, J. Y., Yb, Park, Mk, Lee, Jeon, S. M., McGregor, R. A., et al. (2012). Dose dependent effects of lycopene enriched tomato-wine on liver and adipose tissue in high-fat diet fed rats. Food Chem. 130, 42-48. doi: 10.1016/j.foodchem. 2011.06.050

Klingberg, S., Andersson, H., Mulligan, A., Bhaniani, A., Welch, A., Bingham, S., et al. (2008). Food sources of plant sterols in the epic norfolk population. Eur. J. Clin. Nutr. 62, 695-703. doi: 10.1038/sj.ejcn. 1602765

Koo, S. I., and Noh, S. K. (2001). Phosphatidylcholine inhibits and lysophosphatidylcholine enhances the lymphatic absorption of $\alpha$-tocopherol in adult rats. J. Nutr. 131, 717-722. doi: 10.1093/jn/131.3.717

Kubota, Y., Iso, H., Date, C., Kikuchi, S., Watanabe, Y., Wada, Y., et al. (2011). Dietary intakes of antioxidant vitamins and mortality from cardiovascular disease: the japan collaborative cohort study (JACC) study. Stroke 42, 16651672. doi: 10.1161/STROKEAHA.110.601526

Kuhad, A., Bishnoi, M., Tiwari, V., and Chopra, K. (2009). Suppression of NF$\mathrm{K} \beta$ signaling pathway by tocotrienol can prevent diabetes associated cognitive deficits. Pharmacol. Biochem. Behav. 92, 251-259. doi: 10.1016/j.pbb.2008.12. 012

Kuhad, A., and Chopra, K. (2009). Tocotrienol attenuates oxidative-nitrosative stress and inflammatory cascade in experimental model of diabetic neuropathy. Neuropharmacology 57, 456-462. doi: 10.1016/j.neuropharm.2009. 06.013

Kurano, M., Iso-O, N., Hara, M., Noiri, E., Koike, K., Kadowaki, T., et al. (2011). Plant sterols increased IL- 6 and TNF- $\alpha$ secretion from macrophages, but to a lesser extent than cholesterol. J. Atherosc. Thromb. 18, 373-383. doi: 10.5551/ jat.6999

Kuroda, M., Mimaki, Y., Ohtomo, T., Yamada, J., Nishiyama, T., Mae, T., et al. (2012). Hypoglycemic effects of clove (Syzygium Aromaticum Flower Buds) on genetically diabetic KK-A y mice and identification of the active ingredients. J. Natural Med. 66, 394-399. doi: 10.1007/s11418-011-0593-z

Lai, O. M., and Akoh, C. (2005). Healthful Lipids. London: Routledge.

Lee, E. S., Min Kim, H., Suk Kang, J., Young Lee, E., Yadav, D., Hye Kwon, M., et al. (2016). Oleanolic acid and N-Acetylcysteine ameliorate diabetic nephropathy through reduction of oxidative stress and endoplasmic reticulum stress in a type 2 diabetic rat model. Nephrol. Dial. Transplant. 31, 391-400. doi: 10.1093/ndt/ gfv377

Lee, L. C., Wei, L., Ching Huang, W., Ju Hsu, Y., Ming Chen, Y., and Chang Huang, C. (2015). Hypolipidemic effect of tomato juice in hamsters in high cholesterol diet-induced hyperlipidemia. Nutrients 7, 10525-10537. doi: 10. 3390/nu7125552

Li, Q., and Xing, B. (2016). A phytosterol-enriched spread improves lipid profile and insulin resistance of women with gestational diabetes mellitus: a randomized, placebo-controlled double-blind clinical trial. Diabetes Technol. Ther. 18, 499-504. doi: 10.1089/dia.2016.0103

Li, Y., Wang, J., Gu, T., Yamahara, J., and Li, Y. (2014). Oleanolic acid supplement attenuates liquid fructose-induced adipose tissue insulin resistance through the insulin receptor substrate-1/Phosphatidylinositol 3-Kinase/Akt signaling pathway in rats. Toxicol. Appl. Pharmacol. 277, 155-163. doi: 10.1016/j.taap. 2014.03.016

Li, Y. F., Chang, Y. Y., Huang, H. C., Wu, Y. C., Yang, M. D., and Chao, P. M. (2015). Tomato juice supplementation in young women reduces inflammatory adipokine levels independently of body fat reduction. Nutrition 31, 691-696. doi: 10.1016/j.nut.2014.11.008

Liang, Y. T., Wong, W. T., Guan, L., Tian, X. Y., Ma, K. Y., Huang, Y., et al. (2011). Effect of phytosterols and their oxidation products on lipoprotein profiles and vascular function in hamster fed a high cholesterol diet. Atherosclerosis 219, 124-133. doi: 10.1016/j.atherosclerosis.2011.06.004

Lombardo, D., and Guy, O. (1980). Studies on the substrate specificity of a carboxyl ester hydrolase from human pancreatic juice. II. Action on cholesterol esters and lipid-soluble vitamin esters. BBA Enzymol. 611, 147-155. doi: 10.1016/ 0005-2744(80)90050-9

Luo, H. Q., Shen, J., Ping Chen, C., Ma, X., Lin, C., Ouyang, Q., et al. (2018). Lipidlowering effects of oleanolic acid in hyperlipidemic patients. Chin. J. Natural Med. 16, 339-346. doi: 10.1016/S1875-5364(18)30065-7

Mardones, P., and Rigotti, A. (2004). Cellular mechanisms of vitamin e uptake: relevance in $\alpha$-tocopherol metabolism and potential implications for disease. J. Nutr. Biochem. 15, 252-260. doi: 10.1016/j.jnutbio.2004.02.006

Martín-Pozuelo, G., Navarro-González, I., González-Barrio, R., Santaella, M., García-Alonso, J., Hidalgo, N., et al. (2015). The effect of tomato juice supplementation on biomarkers and gene expression related to lipid metabolism in rats with induced hepatic steatosis. Eur. J. Nutr. 54, 933-944. doi: 10.1007/s00394-014-0770-4

Mathur, P., Ding, Z., Saldeen, T., and Mehta, J. L. (2015). Tocopherols in the prevention and treatment of atherosclerosis and related cardiovascular disease. Clin. Cardiol. 38, 570-576. doi: 10.1002/clc.22422

Matough, F. A., Budin, S. B., Hamid, Z. A., Abdul-Rahman, M., Al-Wahaibi, N., and Mohammed, J. (2014). Tocotrienol-rich fraction from palm oil prevents oxidative damage in diabetic rats. Sultan Qaboos Univ. Med. J. 14, 95-103. doi: 10.12816/0003342

Meydani, M., Kwan, P., Band, M., Knight, A., Guo, W., Goutis, J., et al. (2014). Long-term Vitamin E supplementation reduces atherosclerosis and mortality in Ldlr-/- Mice, but not when fed western style diet. Atherosclerosis 233, 196-205. doi: 10.1016/j.atherosclerosis.2013.12.006 
Minhajuddin, M., Beg, Z. H., and Iqbal, J. (2005). Hypolipidemic and antioxidant properties of tocotrienol rich fraction isolated from rice bran oil in experimentally induced hyperlipidemic rats. Food Chem. Toxicol. 43, 747-753. doi: 10.1016/j.fct.2005.01.015

Miyamoto, K., Shiozaki, M., Shibata, M., Koike, M., Uchiyama, Y., and Gotow, T. (2009). Very-high-dose $\alpha$-Tocopherol supplementation increases blood pressure and causes possible adverse central nervous system effects in strokeprone spontaneously hypertensive rats. J. Neurosci. Res. 87, 556-566. doi: 10. 1002/jnr.21851

Mottillo, S., Filion, K. B., Genest, J., Joseph, L., Pilote, L., Poirier, P., et al. (2010). The metabolic syndrome and cardiovascular risk: a systematic review and meta-analysis. J. Am. Coll. Cardiol. 56, 1113-1132. doi: 10.1016/j.jacc.2010.05. 034

Munteanu, A., Taddei, M., Tamburini, I., Bergamini, E., Azzi, A., and Zingg, J. M. (2006). Antagonistic effects of oxidized low density lipoprotein and $\alpha$ Tocopherol on CD36 scavenger receptor expression in monocytes: involvement of protein kinase $\mathrm{b}$ and peroxisome proliferator-activated Receptor- $\gamma$. J. Biol. Chem. 281, 6489-6497. doi: 10.1074/jbc.M508799200

Muntwyler, J., Hennekens, C. H., Manson, J. E., Buring, J. E., and Gaziano, J. M. (2002). Vitamin supplement use in a low-risk population of US male physicians and subsequent cardiovascular mortality. Arch. Int. Med. 162, 1472-1476. doi: 10.1001/archinte.162.13.1472

Musa-Veloso, K., Poon, T. H., Elliot, J. A., and Chung, C. (2011). A comparison of the LDL-cholesterol lowering efficacy of plant stanols and plant sterols over a continuous dose range: results of a meta-analysis of randomized, placebocontrolled trials. Prostaglandins Leukotrienes and Essential Fatty Acids 85, 9-28. doi: 10.1016/j.plefa.2011.02.001

Mustacich, D. J., Bruno, R. S., and Traber, M. G. (2007). Vitamin E. Vitam. Horm. 76, 1-21. doi: 10.1016/S0083-6729(07)76001-6

Mustad, V. A., Smith, C. A., Ruey, P. P., Edens, N. K., and DeMichele, S. J. (2002). Supplementation with 3 compositionally different tocotrienol supplements does not improve cardiovascular disease risk factors in men and women with hypercholesterolemia. Am. J. Clin. Nutr. 76, 1237-1243. doi: 10.1093/ajcn/76.6. 1237

Newaz, M. A., Yousefipour, Z., Nawal, N., and Adeeb, N. (2003). Nitric oxide synthase activity in blood vessels of spontaneously hypertensive rats: antioxidant protection by $\gamma$-tocotrienol. J. Physiol. Pharmacol. 54, 319-327.

Nishimukai, M., and Hara, H. (2004). Enteral administration of soybean phosphatidylcholine enhances the lymphatic absorption of lycopene, but reduces that of $\alpha$-tocopherol in rats. J. Nutr. 134, 1862-1866. doi: 10.1093/jn/ 134.8.1862

Omenn, G. S., Goodman, G. E., Thornquist, M. D., Balmes, J., Cullen, M. R., Glass, A., et al. (1996). Risk factors for lung cancer and for intervention effects in CARET, the beta-carotene and retinol efficacy trial. J. Natl. Cancer Inst. 88, 1550-1559. doi: 10.1093/jnci/88.21.1550

O’Neill, M. E., Carroll, Y., Corridan, B., Olmedilla, B., Granado, F., and Blanco, I. (2001). A European carotenoid database to assess carotenoid intakes and its use in a five-country comparative study. Br. J. Nutr. 85, 499-507. doi: 10.1079/ bjn 2000284

Ooi, E. M. M., Watts, G. F., Hugh, R., Barrett, P., Chan, D. C., Clifton, P. M., et al. (2007). Dietary plant sterols supplementation does not alter lipoprotein kinetics in men with the metabolic syndrome. Asia Pacific J. Clin. Nutr. 16, 624-631.

Östh, M., Öst, A., Kjolhede, P., Strålfors, P., and Vajreswari, A. (2014). The concentration of $\beta$-carotene in human adipocytes, but not the whole-body adipocyte stores, is reduced in obesity. PloS One 9:e85610. doi: 10.1371/journal. pone. 0085610

Ostlund, R. E., McGill, J. B., Min Zeng, C., Covey, D. F., Stearns, J., Stenson, W. F., et al. (2002). Gastrointestinal absorption and plasma kinetics of Soy $\Delta 5$ Phytosterols and phytostanols in humans. Am. J. Physiol Endocrinol. Metab 282, 911-916. doi: 10.1152/ajpendo.00328.2001

O’byrne, D., Grundy, S., Packer, L., Devaraj, S., Baldenius, K., Hoppe, P. P., et al. (2000). Studies of LDL oxidation following Alfa, Gamma, or Delta - tocotrienyl acetate supplementation of hypercholesterolemic humans. Free Radical Biol. Med. 29, 834-845. doi: 10.1016/s0891-5849(00)00371-3

Pan, Y., Zhou, F., Song, Z., Huang, H., Chen, Y., Shen, Y., et al. (2018). Oleanolic acid protects against pathogenesis of atherosclerosis, possibly via FXR-Mediated Angiotensin (Ang)-(1-7) Upregulation. Biomed. Pharmacother. 97, 1694-1700. doi: 10.1016/j.biopha.2017.11.151
Perona, J. S., Avella, M., Botham, K. M., and Ruiz-Gutierrez, V. (2006). Uptake of triacylglycerol-rich lipoproteins of differing triacylglycerol molecular species and unsaponifiable content by liver cells. Br. J. Nutr. 95, 889-897. doi: 10.1079/ BJN20061730

Perona, J. S., Martínez-González, J., Sanchez-Domínguez, J. M., Badimon, L., and Ruiz-Gutierrez, V. (2004). The unsaponifiable fraction of virgin olive oil in chylomicrons from men improves the balance between vasoprotective and prothrombotic factors released by endothelial cells. J. Nutr. 134, 3284-3289. doi: $10.1093 /$ jn/134.12.3284

Plat, J., Hendrikx, T., Bieghs, V., Jeurissen, M. L., Walenbergh, S. M., van Gorp, P. J., et al. (2014). Protective role of plant sterol and stanol esters in liver inflammation: insights from mice and humans E110758. PLoS One 9:e0110758. doi: 10.1371/journal.pone.0110758

Prévéraud, D. P., Devillard, E., Rouffineau, F., and Borel, P. (2014). Effect of the type of dietary triacylglycerol fatty acids on $\alpha$-tocopherol concentration in plasma and tissues of growing pigs. J. Anim. Sci. 92, 4972-4980. doi: 10.2527/ jas.2013-7099

Quang, T. H., Ngan, N. T. T., Van Minh, C., Van Kiem, P., Thao, N. P., Tai, B. H., et al. (2011). Effect of triterpenes and triterpene saponins from the stem bark of kalopanax pictus on the transactivational activities of three PPAR subtypes. Carbohydr. Res. 346, 2567-2575. doi: 10.1016/j.carres.2011.08.029

Qureshi, A. A., Mo, H., Packer, L., and Peterson, D. M. (2000). Isolation and identification of novel tocotrienols from rice bran with hypocholesterolemic, antioxidant, and antitumor properties. J. Agric Food Chem. 48, 3130-3140. doi: 10.1021/jf000099t

Qureshi, A. A., Sami, S. A., Salser, W. A., and Khan, F. A. (2002). Dose-dependent suppression of serum cholesterol by tocotrienol-rich fraction (TRF25) of rice bran in hypercholesterolemic humans. Atherosclerosis 161, 199-207. doi: 10. 1016/s0021-9150(01)00619-0

Rada, M., Castellano, J. M., Perona, J. S., and Guinda, A. (2015). GC-FID determination and pharmacokinetic studies of oleanolic acid in human serum. Biomed. Chromatogr. 29, 1687-1692. doi: 10.1002/bmc.3480

Rada, M., Ruiz-Gutiérrez, V., and Guinda, A. (2011). Determination of triterpenic acids in human serum by high-performance liquid chromatography: triterpenoid interaction with serum protein. J. Agric. Food Chem. 59, 2308 2313. doi: 10.1021/jf1039537

Ramírez-Espinosa, J. J., Rios, M. Y., López-Martínez, S., López-Vallejo, F., MedinaFranco, J. L., Paoli, P., et al. (2011). Antidiabetic activity of some pentacyclic acid triterpenoids, role of PTP-1B: in vitro, in silico, and in vivo approaches. Eur. J. Med. Chem. 46, 2243-2251. doi: 10.1016/j.ejmech.2011.03.005

Rashidi, B., Hoseini, Z., Sahebkar, A., and Mirzaei, H. (2017). Anti-atherosclerotic effects of Vitamins D and E in suppression of atherogenesis. J. Cell. Physiol. 232, 2968-2976. doi: 10.1002/jcp.25738

Rasool, A. H. G., Yuen, K. H., Yusoff, K., Wong, A. R., and Rahman, A. R. A. (2006). Dose dependent elevation of plasma tocotrienol levels and its effect on arterial compliance, plasma total antioxidant status, and lipid profile in healthy humans supplemented with tocotrienol rich vitamin E. J. Nutr. Sci. Vitaminol. 52, 473-478. doi: $10.3177 /$ jnsv. 52.473

Reboul, E., and Borel, P. (2011). Proteins involved in uptake, intracellular transport and basolateral secretion of fat-soluble vitamins and carotenoids by mammalian enterocytes. Prog. Lipid Res. 50, 388-402. doi: 10.1016/j.plipres.2011.07.001

Reboul, E., Richelle, M., Perrot, E., Desmoulins-Malezet, C., Pirisi, V., and Borel, P. (2006). Bioaccessibility of carotenoids and Vitamin E from their main dietary sources. J. Agric. Food Chem. 54, 8749-8755. doi: 10.1021/jf0 $61818 \mathrm{~s}$

Reboul, E., Soayfane, Z., Goncalves, A., Cantiello, M., Bott, R., Nauze, M., et al. (2012). Respective contributions of intestinal niemann-Pick C1-like 1 and scavenger receptor Class B Type I to cholesterol and tocopherol uptake: in vivo v. in vitro studies. Br. J. Nutr. 107, 1296-1304. doi: 10.1017/S0007114511004405

Reboul, E., Thap, S., Tourniaire, F., André, M., Juhel, C., Morange, S., et al. (2007). Differential effect of dietary antioxidant Classes (Carotenoids, Polyphenols, Vitamins C and E) on lutein absorption. Br. J. Nutr. 97, 440-446. doi: 10.1017/ S0007114507352604

Redlich, C. A., Chung, J. S., Cullen, M. R., Blaner, W. S., Van Bennekum, A. M., Berglund, L., et al. (1999). Effect of long-term beta-carotene and vitamin a on serum cholesterol and triglyceride levels among participants in the carotene and retinol efficacy trial (CARET). Atherosclerosis 143, 427-434. doi: 10.1016/s00219150(98)00303-7 
Reen-Yen, K., Qian, K., Morris-Natschke, S. L., and Hsiung Lee, K. (2009). Plantderived triterpenoids and analogues as antitumor and anti- HIV Agents. Nat. Prod. Rep. 26, 1321-1344. doi: 10.1039/b810774m

Ricciarelli, R., Zingg, J. M., and Azzi, A. (2000). Vitamin E reduces the uptake of oxidized LDL by inhibiting CD36 scavenger receptor expression in cultured aortic smooth muscle cells. Circulation 102, 82-87. doi: 10.1161/01.cir.102.1.82

Rideout, T. C., Harding, S. V., and Jones, P. J. H. (2010). Consumption of plant sterols reduces plasma and hepatic triglycerides and modulates the expression of lipid regulatory genes and de novo lipogenesis in C57BL/6J mice. Mol. Nutr. Food Res. 54(Suppl. 1), 7-13. doi: 10.1002/mnfr.201000027

Ried, K., and Fakler, P. (2011). Protective effect of lycopene on serum cholesterol and blood pressure: meta-analyses of intervention Trials. Maturitas 68, 299310. doi: 10.1016/j.maturitas.2010.11.018

Rocha, V. Z., Ras, R. T., Gagliardi, A. C., Mangili, L. C., Trautwein, E. A., and Santos, R. D. (2016). Effects of phytosterols on markers of inflammation: a systematic review and meta-analysis. Atherosclerosis 248, 76-83. doi: 10.1016/ j.atherosclerosis.2016.01.035

Rondanelli, M., Monteferrario, F., Faliva, M. A., Perna, S., and Antoniello, N. (2013). Key points for maximum effectiveness and safety for cholesterollowering properties of plant sterols and use in the treatment of metabolic syndrome. J. t Sci. Food Agric. 93, 2605-2610. doi: 10.1002/jsfa.6174

Roodenburg, A. J. C., Leenen, R., Van Het Hof, K. H., Weststrate, J. A., and Tijburg, L. B. M. (2000). Amount of fat in the diet affects bioavailability of lutein esters but not of $\alpha$-Carotene, $\beta$-Carotene, and Vitamin E in humans. Ame. J. Clin. Nutr. 71, 1187-1193. doi: 10.1093/ajcn/71.5.1187

Saaby, L., Moesby, L., Wind Hansen, E., and Brøgger Christensen, S. (2011). Isolation of immunomodulatory triterpene acids from a standardized rose hip powder (Rosa Canina L.). Phytother. Res. 25, 195-201. doi: 10.1002/ptr.3241

Saha, P. K., Reddy, V. T., Konopleva, M., Andreeff, M., and Chan, L. (2010). The Triterpenoid 2-Cyano-3,12-Dioxooleana-1,9-Dien-28-Oic-Acid Methyl Ester Has Potent Anti-Diabetic Effects in Diet-Induced Diabetic Mice and Lepr Db/Db Mice. J. Biol. Chem. 285, 40581-40592. doi: 10.1074/jbc.M110.176545

Saldeen, T., Li, D., and Mehta, J. L. (1999). Differential effects of $\alpha$ - and $\gamma$ tocopherol on low-density lipoprotein oxidation, superoxide activity, platelet aggregation and arterial thrombogenesis. J. Am. College Cardiol. 34, 1208-1215. doi: 10.1016/S0735-1097(99)00333-2

Sangeetha, K. N., Sujatha, S., Shanmuganathan Muthusamy, V., Anand, S., Nithya, N., Velmurugan, D., et al. (2010). 3 $\beta$-Taraxerol of mangifera indica, a PI3K dependent dual activator of glucose transport and glycogen synthesis in 3T3L1 adipocytes. Biochim. Biophys. Acta Gen. Sub. 1800, 359-366. doi: 10.1016/j. bbagen.2009.12.002

Santos-Lozano, J. M., Rada, M., Lapetra, J., Guinda, A., Jiménez-Rodríguez, M. C., Cayuela, J. A., et al. (2019). Prevention of type 2 diabetes in prediabetic patients by using functional olive oil enriched in oleanolic acid: the PREDIABOLE study, a randomized controlled trial. Diabetes Obes. Metab. 21, 2526-2534. doi: $10.1111 /$ dom. 13838

Sato, H., Genet, C., Strehle, A., Thomas, C., Lobstein, A., Wagner, A., et al. (2007). Anti-hyperglycemic activity of a TGR5 agonist isolated from Olea Europaea. Biochem. Biophys. Res. Commun. 362, 793-798. doi: 10.1016/j.bbrc.2007.06.130

Saura-Calixto, F., Serrano, J., and Goñi, I. (2007). Intake and bioaccessibility of total polyphenols in a whole diet. Food Chem. 101, 492-501. doi: 10.1016/j. foodchem.2006.02.006

Schultz, M., Leist, M., Petrzika, M., Gassmann, B., and Brigelius-Flohé, R. (1995). Novel urinary metabolite of alpha-tocopherol, Alpha-CEHC, as an Indicator of an Adequate Vitamin E Supply Am. J. Clin. Nutr. 2, 1527-1534. doi: 10.1093/ ajcn/62.6.1527S

Sialvera, T. E., Pounis, G. D., Koutelidakis, A. E., Richter, D. J., Yfanti, G., Kapsokefalou, M., et al. (2012). Phytosterols supplementation decreases plasma small and dense LDL levels in metabolic syndrome patients on a westernized type diet. Nutr. Metab. Cardiovas. Dis. 22, 843-848. doi: 10.1016/j.numecd. 2010.12.004

Siddiqui, S., Rashid Khan, M., and Siddiqui, W. A. (2010). Comparative hypoglycemic and nephroprotective effects of tocotrienol rich fraction (TRF) from palm oil and rice bran oil against hyperglycemia induced nephropathy in type 1 diabetic rats. Chem. Biol. Interact. 188, 651-658. doi: 10.1016/j.cbi.2010. 08.010

Skarke, C., Kuczka, K., Tausch, L., Werz, O., Rossmanith, T., Barrett, J. S., et al. (2012). Increased bioavailability of 11-Keto- $\beta$-boswellic acid following single oral dose frankincense extract administration after a standardized meal in healthy male volunteers: modeling and simulation considerations for evaluating drug exposures. J. Clin. Pharmacol. 52, 1592-1600. doi: 10.1177/ 0091270011422811

Sluijs, I., Beulens, J. W. J., Grobbee, D. E., and van der Schouw, Y. T. (2009). Dietary carotenoid intake is associated with lower prevalence of metabolic syndrome in middle-aged and elderly men. J. Nutr. 139, 987-992. doi: 10.3945/jn.108.101451

Soobrattee, M. A., Neergheen, V. S., Luximon-Ramma, A., Aruoma, O. I., and Bahorun, T. (2005). Phenolics as potential antioxidant therapeutic agents: mechanism and actions. Mutat. Res. 579, 200-213. doi: 10.1016/j.mrfmmm. 2005.03.023

Sozen, E., Yazgan, B., Sahin, A., Ince, U., and Kartal Ozer, N. (2018). High cholesterol diet-induced changes in oxysterol and scavenger receptor levels in heart tissue. Oxid. Med. Cell. Longev. 2018:8520746. doi: 10.1155/2018/8520746

Stephens, N. G., Parsons, A., Schofield, P. M., Kelly, F., Cheeseman, K., Mitchinson, M. J., and Brown, M. J. (1996). Randomised controlled trial of vitamin E in patients with coronary disease: the Cambridge Heart Antioxidant Study (CHAOS). Lancet 347, 781-786. doi: 10.1016/s0140-6736(96)90866-1

Su, S., Wu, G., Cheng, X., Fan, J., Peng, J., Su, H., et al. (2018). Oleanolic acid attenuates pcbs-induced adiposity and insulin resistance via hnflb-mediated regulation of redox and PPAR $\gamma$ signaling. Free Rad. Biol. Med. 124, 122-134. doi: 10.1016/j.freeradbiomed.2018.06.003

Sung, H. Y., Kang, S. W., Kim, J. L., Li, J., Lee, E. S., Gong, J. H., et al. (2010). Oleanolic acid reduces markers of differentiation in 3T3-L1 adipocytes. Nutr. Res. 30, 831-839. doi: 10.1016/j.nutres.2010.10.001

Suzuki, K., Ito, Y., Inoue, T., and Hamajima, N. (2011). Inverse association of serum carotenoids with prevalence of metabolic syndrome among japanese. Clin. Nutr. 30, 369-375. doi: 10.1016/j.clnu.2010.12.006

Sy, C., Gleize, B., Dangles, O., Landrier, J. F., Caris Veyrat, C., and Borel, P. (2012). Effects of physicochemical properties of carotenoids on their bioaccessibility, intestinal cell uptake, and blood and tissue concentrations. Mol. Nutr. Food Res 56, 1385-1397. doi: 10.1002/mnfr.201200041

Talati, R., Sobieraj, D. M., Makanji, S. S., Phung, O. J., and Coleman, C. I. (2010). The comparative efficacy of plant sterols and stanols on serum lipids: a systematic review and meta-analysis. J. Am. Dietet. Assoc. 110, 719-726.

Teodoro, T., Zhang, L., Alexander, T., Yue, J., Vranic, M., and Volchuk, A. (2008). Oleanolic acid enhances insulin secretion in pancreatic $\beta$-Cells. FEBS Lett. 582, 1375-1380. doi: 10.1016/j.febslet.2008.03.026

Traber, M. G., and Atkinson, J. (2007). Vitamin E, antioxidant and nothing more. Free Rad. Biol. Med. 43, 4-15. doi: 10.1016/j.freeradbiomed.2007.03.024

Traber, M. G., Leonard, S. W., Ebenuwa, I., Violet, P. C., Wang, Y., Niyyati, M., et al. (2019). ). Vitamin E absorption and kinetics in healthy women, as modulated by food and by Fat, studied using 2 deuterium-labeled $\alpha$-tocopherols in a 3-phase crossover design. Am. J. Clin. Nutr. 110, 1148-1167. doi: 10.1093/ajcn/nqz172

Trautwein, E. A., Koppenol, W. P., De Jong, A., Hiemstra, H., Vermeer, M. A., Noakes, M., et al. (2018). Plant sterols lower LDL-cholesterol and triglycerides in dyslipidemic individuals with or at risk of developing type 2 diabetes; a randomized, double-blind, placebo-controlled study. Nutr. Diabetes 8:30. doi: 10.1038/s41387-018-0039-8

Tsai, S. J., and Yin, M. C. (2008). Antioxidative and anti-inflammatory protection of oleanolic acid and ursolic acid in PC12 cells. J. Food Sci. 73, 174-178. doi: 10.1111/j.1750-3841.2008.00864.x

Vafa, M., Haghighat, N., Moslehi, N., Eghtesadi, S., and Heydari, I. (2015). Effect of tocotrienols enriched canola oil on glycemic control and oxidative status in patients with type 2 diabetes mellitus: a randomized double-blind placebocontrolled clinical trial. J. Rese. Med. Sci. 20, 540-547. doi: 10.4103/1735-1995. 165945

Valerio, M., and Awad, A. B. (2011). $\beta$-sitosterol down-regulates some pro-inflammatory signal transduction pathways by increasing the activity of tyrosine phosphatase SHP-1 in J774A.1 Murine Macrophages. Int. Immunopharmacol. 11, 1012-1017. doi: 10.1016/j.intimp.2011.02.018

Valsta, L. M., Lemström, A., Ovaskainen, M. L., Lampi, A. M., Toivo, J., Korhonen, T., et al. (2004). Estimation of plant sterol and cholesterol intake in finland: quality of new values and their effect on intake. Br. J. Nutr. 92, 671-678. doi: 10.1079/bjn20041234

Venturi, F., Testai, L., Flori, L., Donnini, S., Calderone, V., and Zinnai, A. (2019). The nutraceutical value of olive oil and its bioactive constituents on the cardiovascular system. focusing on main strategies to slow down its 
quality decay during production and storage. Nutrients 11:1962. doi: 10.3390/ nu11091962

Wang, M., Zhao, T., Liu, Y., Wang, Q., Xing, S., Li, L., et al. (2017). Ursolic acid liposomes with chitosan modification: promising antitumor drug delivery and efficacy. Mater. Sci. Eng. C 71, 1231-1240. doi: 10.1016/j.msec.2016.11.014

Wang, X., Chen, Y., Abdelkader, D., Hassan, W., Sun, H., and Liu, J. (2015). Combination therapy with oleanolic acid and metformin as a synergistic treatment for diabetes. J. Diabetes Res. 2015:973287. doi: 10.1155/2015/973287

Wang, X., Liu, R., Zhang, W., Zhang, X., Liao, N., Wang, Z., et al. (2013). Oleanolic acid improves hepatic insulin resistance via antioxidant, hypolipidemic and anti-inflammatory effects. Mol. Cell. Endocrinol. 376, 70-80. doi: 10.1016/j.mce. 2013.06.014

Wang, X., Ye, X. L., Liu, R., Chen, H. L., Bai, H., Liang, X., et al. (2010). Antioxidant activities of oleanolic acid in vitro: possible role of Nrf2 and MAP kinases. Chem. Biol. Interact. 184, 328-337. doi: 10.1016/j.cbi.2010. 01.034

Westphal, A., and Böhm, V. (2015). Carotenoids. Special 62, 196-207. doi: 10.4455/ eu. 2015.036

Whalley, N. M., Pritchard, L. E., Smith, D. M., and White, A. (2011). Processing of proglucagon to GLP-1 in pancreatic $\alpha$-cells: is this a paracrine mechanism enabling GLP-1 to act on $\beta$-Cells J. Endocrinol. 211, 99-106. doi: 10.1530/JOE11-0094

Wong, S. K., Chin, K. Y., Suhaimi, F. H., Ahmad, F., and Ima-Nirwana, S. (2017). Vitamin $\mathrm{E}$ as a potential interventional treatment for metabolic syndrome: evidence from animal and human studies. Front. Pharmacol. 8:444. doi: 10. 3389/fphar.2017.00444

Woo, S. L., Im, K. R., Park, Y. D., Sung, N. D., and Jeong, T. S. (2006). Human ACAT-1 and ACAT-2 inhibitory activities of pentacyclic triterpenes from the leaves of lycopus lucidus TURCZ. Biol. Pharmaceut. Bull. 29, 382-384. doi: $10.1248 /$ bpb. 29.382

Xiao, M., Chen, G. D., Zeng, F. F., Qiu, R., Shi, W. Q., Lin, J. S., et al. (2019). Higher serum carotenoids associated with improvement of non-alcoholic fatty liver disease in adults: a prospective study. Eur. J. Nutr. 58, 721-730. doi: 10.1007/s00394-018-1678-1

Yabuzaki, J. (2017). Carotenoids database: structures, chemical fingerprints and distribution among organisms. Database 2017, 1-11. doi: 10.1093/database/ bax004

Yamai, H., Sawada, N., Yoshida, T., Seike, J., Takizawa, H., Kenzaki, K., et al. (2009). Triterpenes augment the inhibitory effects of anticancer drugs on growth of human esophageal carcinoma cells in vitro and suppress experimental metastasis in vivo. Int. J. Cancer 125, 952-960. doi: 10.1002/ijc.24433

Yang, Z. G., Li, H. R., Wang, L. Y., Li, Y. H., Lu, S. G., Wen, X. F., et al. (2007). Triterpenoids from hippophae rhamnoides 1 . and their nitric oxide productioninhibitory and DPPH radical-scavenging activities. Chem. Pharmaceut. Bull. 55, 15-18. doi: 10.1248/cpb.55.15

Yin, M. C., and Chan, K. C. (2007). Nonenzymatic antioxidative and antiglycative effects of oleanolic acid and ursolic acid. J. Agric. Food Chem. 55, 7177-7181. doi: $10.1021 / \mathrm{jf} 071242 \mathrm{~m}$

Yoshikawa, S., Morinobu, T., Hamamura, K., Hirahara, F., Iwamoto, T., and Tamai, H. (2005). The effect of $\gamma$-Tocopherol administration on $\alpha$-tocopherol levels and metabolism in humans. Eur. J. Clin. Nutr. 59, 900-905. doi: 10.1038/sj.ejcn. 1602154

Zaiden, N., Yap, W., Ong, S., Xu, C., Teo, V., Chang, C., et al. (2010). Gamma delta tocotrienols reduce hepatic triglyceride synthesis and VLDL secretion. J. Atheroscler. Thromb. 17, 1019-1032. doi: 10.5551/jat.4911

Zeng, X. Y., Wang, J. Y. P., Cantley, K., Iseli, T. J., Molero, J. C., Hegarty, B. D., et al. (2012). Oleanolic acid reduces hyperglycemia beyond treatment period with Akt/FoxO1-Induced suppression of hepatic gluconeogenesis in type-2 diabetic mice. PLoS One 7:e0042115. doi: 10.1371/journal.pone.0042115

Zhao, L., Kang, I., Fang, X., Wang, W., Lee, M. A., Hollins, R. R., et al. (2015). Gamma-tocotrienol attenuates high-fat diet-induced obesity and insulin resistance by inhibiting adipose inflammation and M1 macrophage recruitment. Int. J. Obes. 39, 438-446. doi: 10.1038/ijo.2014.124

Zhu, Z., Qian, Z., Yan, Z., Zhao, C., Wang, H., and Ying, G. (2013). A phase I pharmacokinetic study of ursolic acid nanoliposomes in healthy volunteers and patients with advanced solid tumors. Int. J. Nanomed. 8, 129-136. doi: $10.2147 / \mathrm{IJN} . S 38271$

Conflict of Interest: The authors declare that the research was conducted in the absence of any commercial or financial relationships that could be construed as a potential conflict of interest.

Copyright (C) 2020 Castellano, Espinosa and Perona. This is an open-access article distributed under the terms of the Creative Commons Attribution License (CC BY). The use, distribution or reproduction in other forums is permitted, provided the original author(s) and the copyright owner(s) are credited and that the original publication in this journal is cited, in accordance with accepted academic practice. No use, distribution or reproduction is permitted which does not comply with these terms. 